\title{
No effect of sex on ethanol intake and preference after dopamine transporter (DAT) knockdown in adult mice
}

\author{
Amine Bahi ${ }^{1}$ • Jean-Luc Dreyer ${ }^{2}$
}

\begin{abstract}
Rationale Dopamine levels are controlled in part by transport across the cell membrane by the dopamine transporter (DAT), and recent evidence showed that a polymorphism in the gene encoding DAT is associated with alcoholism. However, research in animal models using DAT knockout mice has yielded conflicting results.

Objectives The present study was planned to evaluate the effects of DAT knockdown in the nucleus accumbens (Nacc) on voluntary ethanol consumption and preference in male and female C57BL/6J mice.

Methods For this purpose, animals were stereotaxically injected with DAT siRNA-expressing lentiviral vectors in the Nacc, and using a voluntary, continuous access two-bottle choice model of alcohol, we investigated the importance of accumbal DAT expression in voluntary alcohol intake and preference. We also investigated the effects of DAT knockdown on saccharin and quinine consumption and ethanol metabolism.

Results We show that females consumed more alcohol than males. Interestingly, DAT knockdown in the Nacc significantly decreased alcohol intake and preference in both groups, but no significant sex by group interaction was observed. Also, DAT knockdown did not alter total fluid consumption, saccharin or quinine consumption, or blood ethanol concentrations. Using Pearson correlation, results indicated a strong positive relationship between DAT mRNA expression and ethanol consumption and preference.

Conclusions Taken together, these data provide further evidence that DAT plays an important role in controlling ethanol intake and that accumbal DAT contributes in the modulation of the reinforcing effects of ethanol. Overall, the results suggest that DAT inhibitors may be valuable in the pharmacotherapy of alcoholism.
\end{abstract}

Keywords Alcoholism $\cdot$ DAT $\cdot$ Dopamine transporter $\cdot$ Ethanol $\cdot$ Lentivirus $\cdot$ shRNA $\cdot$ Two-bottle choice

$\begin{array}{ll}\text { Abbreviations } \\ \text { BEC } & \text { Blood ethanol concentration } \\ \text { DAT } & \text { Dopamine transporter } \\ \text { LV } & \text { Lentiviral vectors } \\ \text { Nacc } & \text { Nucleus accumbens }\end{array}$

Electronic supplementary material

Amine Bahi

amine.bahi@gmail.com

1 Department of Anatomy, United Arab Emirates University, Tawam Medical Campus, Al Ain, United Arab Emirates

2 Division of Biochemistry, Department of Medicine, University of Fribourg, 1700 Fribourg, Switzerland
shRNA Short hairpin RNA

TBC Two-bottle choice

\section{Introduction}

Alcoholism is a common, heritable, chronic relapsing disorder, with enormous societal impact. Thus, understanding the molecular mechanisms involved in the neuropathophysiology of alcoholism is critical to characterize individuals' risk and to develop efficient prevention and treatment strategies. However, despite extensive efforts directed toward the development of medication to treat alcoholism and alcohol use disorders, no effective pharmacotherapy is presently in clinical use. Given the obvious importance of dopaminergic neurotransmission in alcoholism, the development of drugs that target the dopaminergic system in general, and the dopamine 
transporter (DAT) in particular, may hold promise as a potential pharmacotherapy for alcoholism.

Extracellular dopamine concentrations are the net result of release and clearance from the synaptic space. In the mammalian CNS, uptake through the plasma membrane DAT is the main mechanism for regulating extracellular dopamine levels (Benoit-Marand et al. 2000). In fact, the main mechanism for clearing extracellular dopamine of the dorsal striatum and Nacc involves the neuronal DAT, rather than metabolism or diffusion (Cass et al. 1993), with the Nacc being more sensitive to the effects of inhibitors of dopamine uptake than is the dorsal striatum (Cass et al. 1993). By contrast, and because the norepinephrine transporter (NET) is present in much greater concentrations than DAT, in the prefrontal cortex (PFC), dopamine uptake in the PFC depends primarily on NET (Moron et al. 2002). DAT is a member of a larger family of sodiumand chloride-dependent transporters, which includes GABA, noradrenaline, serotonin, and glycine carriers [for review, see Gether et al. 2006]. DAT is a membrane protein located on dopaminergic cells, and like other monoamine transporters, it has 12 transmembrane domains with intracellular $\mathrm{N}$ - and $\mathrm{C}$ termini and belongs to the SLC6A family of $\mathrm{Na}^{+} / \mathrm{Cl}^{-}$-dependent symporters (Gainetdinov and Caron 2003). DAT is not ubiquitously expressed but is restricted to dopaminergic neurons within well-known neurological pathways associated to dopamine neurotransmission. In fact, Richtand and colleagues used a highly sensitive and specific nuclease protection assay and showed that DAT mRNA was located solely in cell bodies of dopaminergic neurons, with the main expression seen in the substantia nigra/ventral tegmentum (SN/VTA), and lower but measurable expression within the hypothalamus (Richtand et al. 1995), with a different set of findings revealing an agedependent reduction in the number of SN DATimmunoreactive neurons (Ma et al. 1999). Also, immunocytochemistry using highly specific monoclonal antibodies indicated that mesencephalic DAT immunoreactivity was enhanced in the dendrites and cell bodies of neurons in the SN pars compacta and VTA, with a dense and heterogeneous staining in the striatum and nucleus accumbens (Ciliax et al. 1999). Positron emission tomography with $\left[{ }^{11} \mathrm{C}\right]$ altropane indicated that DAT is located also in the midbrain and prefrontal cortex (Madras et al. 2005).

At the functional level, pharmacological or genetic manipulation of DAT, using knockout (KO) mice, resulted in disturbances of many behaviors. For example, DAT KO mice exhibit regular deficiency in prepulse inhibition (PPI) of the acoustic startle reflex, which is an operational task of sensorimotor gating (Ralph et al. 2001), that was associated with deficits of neuronal development in the prefrontal cortex (Kasahara et al. 2011). Moreover, during dopamine neuron neurogenesis, maternal cocaine exposure has long-lasting effects on dopaminergic neuronal functions lasting into early adulthood (Salvatore et al. 2004). This effect was correlated, at least in part, with stable DAT protein levels (Salvatore et al. 2004). As for cognition, nicotine treatment significantly improved $\mathrm{KO}$ mice impairment in cued spatial learning and memory tasks (Weiss et al. 2007). Because dopamine mediates food rewarding value, methylphenidate (DAT inhibitor) decreased energy intake from fat and carbohydrates in obese adolescents (Danilovich et al. 2014), suggesting that DAT is important for eating behavior. Also, since dopamine content in terminal areas was affected by seizure activity, the chemoconvulsant pentylenetetrazol reduced DAT mRNA expression in the substantia nigra pars compacta/ventral tegmentum area in the rat (Szot et al. 1997). Again, as catecholamines are known to regulate thermogenesis and circadian rhythms, the Drosophila melanogaster DAT-defective mutant showed a short sleep phenotype (Kume et al. 2005; Tomita et al. 2015), that was associated with increased metabolic rate and a thermophobic phenotype - a preference for lower temperatures compared to wild-type flies (Ueno et al. 2012). Likewise, a recent study reported that increased cortical dopamine/DAT, facilitated the clinical efficiency of the norepinephrine reuptake inhibitor, tapentadol, in neuropathic pain (Benade et al. 2017).

In addition, many studies have shown that DAT is implicated in the neuropathophysiology of affective disorders such as addiction to psychostimulants, like amphetamine and cocaine, that disturbs transporter trafficking, which in turn triggers a rapid insertion or removal of membranous DAT (Schmitt and Reith 2010). Furthermore, local infusions of nonviral small interfering RNAs into the ventral tegmental area/substantia nigra increased stress-induced immobility in the tail-suspension test indicating a prodepressant-like phenotype in mice (Chen and Lai 2010). However, Perona and coworkers showed that, compared to WT controls, DAT KO mice displayed significantly higher consumption of sucrose solution suggesting decreased anhedonia, decreased immobility, and increased swimming in the forced-swim test indicating an antidepressant-like phenotype (Perona et al. 2008). This outcome is paralleled by a significantly reduced anxiety-like behavior using the open field test (Pogorelov et al. 2005). But findings from positron emission tomography (PET) or single photon emission computed tomography (SPECT) studies, investigating DAT function in the striatum of patients with schizophrenia, yielded several conflicting results [for review, see Brunelin et al. 2013]. Because DAT maintains dopaminergic homeostasis, several reports showed that DAT KO mice exhibit increased hyperactivity and stereotypic behaviors (Giros et al. 1996), altered sensorimotor gating (Ralph et al. 2001), and impaired learning and working memory (Li et al. 2010), all of which reflect certain symptoms of schizophrenia (Gainetdinov et al. 2001) and attention-deficit hyperactivity disorder (ADHD) (Madras et al. 2005). Again, since central dopaminergic neurotransmission is significantly involved in the pathogenesis of autism spectrum disorder (ASD), Cartier 
and colleagues identified rare, inherited, functional missense variant in DAT gene (resulting in an Arg to Trp substitution at site 51) in separate individuals with ASD (Cartier et al. 2015), suggesting a major contribution of DAT in ASD. On the other hand, numerous lines of evidence support a "dopaminergic hypothesis" in the pathophysiology of Gilles de la Tourette syndrome (TS). In fact, and compared to healthy controls, patients severely affected with TS showed significantly lower methylation levels of DAT gene (Muller-Vahl et al. 2017), suggesting high DAT expression levels. These observations are in line with the results from another study in which a high level of DAT in bilateral striatum was found in drug-naive TS patients compared with that in normal controls (Liu et al. 2010), indicating that hyperfunctional DAT might be involved in the pathophysiology of TS. By contrast, drug-naive patients with obsessive-compulsive disorder (OCD) have a significantly reduced availability of striatal DAT (Hesse et al. 2005), and treatment with the selective serotonin reuptake inhibitor citalopram increased DAT availability by about $40 \%$ (Pogarell et al. 2005), indicating an imbalanced monoaminergic neurotransmitter modulation in OCD.

For alcohol use disorders, a link between a variable number tandem repeat (VNTR) polymorphism in the $3^{\prime}$ untranslated region of DAT and several alcohol withdrawal symptoms has been reported (Sander et al. 1997). Interestingly, post mortem brain samples from human alcoholics exhibited a significant downregulation of DAT binding sites in striatal tissue (Hirth et al. 2016), which was in line with earlier observations using post mortem tissue samples (Bergstrom et al. 2001). Further, using the immediate dopamine precursor $\left[{ }^{18} \mathrm{~F}\right] \mathrm{DOP}$, human in vivo studies revealed that dopamine synthesis was increased but DAT availability was reduced in alcoholics (Tiihonen et al. 1998). Also, SPECT imaging indicated significantly lower DAT binding in alcoholics on admission for detoxification than in the nonalcoholics (Laine et al. 1999). Furthermore, after abstinence (4 weeks), DAT binding levels increased in the alcoholics to reach the levels of the healthy controls (Laine et al. 1999). However, Volkow and colleagues reported that alcoholics showed DAT binding levels similar to those in nonalcoholics (Volkow et al. 1996). The discrepancies between the above-mentioned studies could be, at least in part, explained by some of their limitations, such as the small size of the study samples, and the heterogeneity of the patients, although findings may not generalize to other ethnic backgrounds. Also, these studies did not inspect other aspects of the patients' genetic environment or their interactions with their environment. The critical importance of DAT implication in the neuropathophysiology of alcoholism was also demonstrated through studies using DAT KO mice that have produced divergent findings. In fact, a study by Savelieva and colleagues found that the partial deletion of DAT, in heterozygotes, resulted in increased fluid consumption in female mice but does not change ethanol preference in either sex, whereas complete deletion of DAT, in KO mice, reduces ethanol preference in females (Savelieva et al. 2002). On the contrary, a totally independent study, using different transgenic animals, reported that deletion of DAT gene increased ethanol consumption in male $\mathrm{KO}$ mice, while female $\mathrm{KO}$ mice had higher ethanol preference (Hall et al. 2003). These contradictory observations and opposing phenotypic changes are possibly due to mechanisms of functional compensation commonly observed in KO mice. Therefore, to circumvent these discrepancies, using a different approach we tested the novel hypothesis that DAT in the Nacc contributes to the reinforcing properties of ethanol.

In this study, we used a standard two-bottle choice "TBC" drinking procedure to model ethanol consumption and preference in mice. Most of the studies used TBC procedures, which involve offering the possibility to drink either a diluted ethanol-containing solution (concentrations range from 3 to $30 \%$ ) or water, for a fixed amount of time (typically in continuous $24-\mathrm{h}$ periods). The ratio of ethanol intake relative to the total fluid intake is considered a measure of preference. In some cases, the TBC access to ethanol could be intermittent (Rosenwasser et al. 2013), but not always (Crabbe et al. 2012), which results in higher ethanol intake compared to continuous access. The strength of the behavioral procedures was highlighted by work showing that genetically identical mice tested in differing housing and experimental conditions influenced the outcomes from several different laboratories. Although the different research groups took drastic measures to preserve matching experimental conditions, the researchers could not justify $52 \%$ of the discrepancy in ethanol intake. Regardless, one of the most reliable behaviors across laboratories was ethanol intake in a 6-day TBC procedure (Crabbe et al. 1999). Even though, like any model, the TBC procedure does not reproduce the full spectrum of mechanisms involved in human alcohol consumption, it is considered relevant to human alcohol drinking (Dole 1986; Li et al. 1979) and is extensively used in experimental studies of alcohol drinking.

In the current series of experiments, we were specifically interested in determining if reduced ethanol consumption and preference could be achieved when lentiviral-mediated delivery of shRNA was used to target the accumbal DAT mRNAs in adult male and female C57BL/6 mice. In support of our hypothesis and as stated above, DAT mRNA is highly enriched in the Nacc (Ciliax et al. 1999), and there is strong evidence that accumbal DAT contributes critically to ethanolrelated behaviors (Hall et al. 2003; Morice et al. 2010; Savelieva et al. 2002). Therefore, we designed lentiviral vectors that expressed shRNA designed to target DAT mRNAs. These vectors, successfully used in our previous studies (Adriani et al. 2009; Adriani et al. 2010; Boyer and Dreyer 2008), were bilaterally infused into the Nacc of male and 
female C57BL/6 mice and subsequently these animals were assessed for voluntary ethanol intake and preference using a standard TBC drinking procedure.

\section{Materials and methods}

\section{Animals}

Adult $(10-12$ weeks) male $(n=20)$ and female $(n=21)$ C57BL/6J mice were obtained from the local breeding facility of the College of Medicine \& Health Sciences and maintained in a temperature-controlled $\left(\sim 22^{\circ} \mathrm{C}\right)$ colony room with a 12 -h light-dark cycle (06:00 to 18:00 lights on). The mice were housed in groups until they underwent stereotaxic surgery, after which they were singly housed throughout all subsequent testing. Bedding was produced locally and autoclaved before use. Water and food were available ad libitum throughout the experiment. Standard rodents' chow diet was obtained from the National Feed and Flour Production and Marketing Company LLC (Abu Dhabi, UAE). The local Animal Research Ethics Committee approved the procedures (Application Reference No. A27-12).

\section{Drugs}

For the TBC drinking procedure, the ethanol solution (10\%, $v / v$ ) was prepared from Ethanol absolute BioChemica (Panreac Quimica SAU, Barcelona, Spain) and diluted using tap water. For taste sensitivity, saccharin sodium salt dihydrate $(0.04$ and $0.08 \% ; w / v)$ and quinine hemisulfate (35 and $70 \mu \mathrm{M} ; w / v$ ) were dissolved in tap water. For the blood ethanol concentration (BEC) experiments, ethanol was dissolved in physiological saline $0.9 \%$ sodium chloride and sterile water and has been used for intraperitoneal (i.p.) injections at a dose of $1.2 \mathrm{~g} / \mathrm{kg}$.

\section{Cloning of DAT shRNAs and lentivirus production}

Plasmid construction was described in previously published work from our laboratory (Adriani et al. 2009, 2010; Boyer and Dreyer 2008). In brief, small interfering RNA (siRNA) were designed against rat DAT mRNA, and sequences were confirmed against available data to ensure DAT specificity. The pairwise sequence similarity search using BLAST algorithm indicated a $96 \%$ homology between rat and mouse sequences. The following target within DAT sequence was selected, based on Hannon's design criterion (http://katahdin. cshl.org: 9331/RNAi/html/rnai.html): AGC CAT GGA TGG CAT CAG AGC ATA CCT. An XhoI restriction site was added at $3^{\prime}$ and a U6-3'-specific $10 \mathrm{mer}$ at 5', using the pSilencer 1.0-U6 (Ambion, UK) as a template and a U6 promoter-specific forward primer containing Bam HI restriction site (5'-GCG GAT CCC GCT CTA GAA CTA GTG $C-3^{\prime}$ ). The siRNA target was added to the mouse U6 promoter by PCR, using the following PCR program: $120 \mathrm{~s}$ at $94{ }^{\circ} \mathrm{C}$ (initial denaturation) followed by 35 cycles $(45 \mathrm{~s}$ at $94{ }^{\circ} \mathrm{C}, 45 \mathrm{~s}$ at $64{ }^{\circ} \mathrm{C}$, and $45 \mathrm{~s}$ at $72{ }^{\circ} \mathrm{C}$ ) in $4 \%$ dimethyl sulfoxide (DMSO). The PCR product was digested with BamHI and XhoI, cloned into similar sites into pTK431 (graciously provided by Dr. Tal Kafri, UNC Gene Therapy Center), and predigested with the same restriction enzymes. The ligation product was amplified using DH5 $\alpha$-competent bacteria and DNA minipreps were sequenced to verify the integrity of the construct. The control vector (Mock) consisted of an empty pTK 31 .

Mock and DAT siRNA-expressing lentiviral vectors (siDAT) were packaged through the co-transfection of human embryonic kidney 293T (HEK293T) cells, using calcium phosphate, with a LV packaging vector ( $\mathrm{p} \Delta \mathrm{NRF})$ and a vesicular stomatitis virus glycoprotein pseudotyping plasmid (pMDG-VSV-G). Medium was collected at 24 and $48 \mathrm{~h}$ post transfection and virus concentrated by centrifugation. The supernatant was removed, and the virus was suspended in sterile cold phosphate-buffered saline (PBS) supplemented with $1 \%$ bovine serum albumin (BSA). Viral titers (approximately $10^{8}-10^{9}$ units $/ \mathrm{mL}$ ) were determined using a p24 antigen ELISA kit (Bahi et al. 2004, 2005a, b).

\section{Stereotaxic injection of lentiviral vectors into the Nacc}

For viral injection, the mice were first anesthetized with a cocktail of ketamine (100 mg/kg, i.p.) and xylazine $(10 \mathrm{mg} / \mathrm{kg}$, i.p.) and placed in a stereotaxic frame. A craniotomy was drilled and a $5-\mu \mathrm{L}$ Hamilton microsyringe filled with a viral solution was lowered into the Nacc using the following coordinates: $+1.7 \mathrm{~mm} \mathrm{AP,} \pm 0.75 \mathrm{~mm} \mathrm{ML}$, and $4.5 \mathrm{~mm}$ ventral from the dural surface (Bahi 2016; Bahi et al. 2016; Bahi and Dreyer 2012, 2014; Franklin and Paxinos 1997). For each injection, $0.5 \mu \mathrm{L}$ of viral particles were infused at a rate of $0.1 \mu \mathrm{L} / \mathrm{min}$. Following vector administration, the Hamilton microsyringe was left in situ for an additional $10 \mathrm{~min}$ to prevent backflow. After recovery, the mice were singly housed with access to two bottles and left to recover 10 days before behavioral experiments started. After recovery, the sex and virus combination yielded four experimental groups: malemock $n=9$, male-siDAT $n=11$, female-mock $n=10$, and female-siDAT $n=11$. The experimental timeline is depicted in Fig. 1a.

\section{Continuous voluntary access to alcohol in a two-bottle choice drinking paradigm}

Voluntary ethanol consumption and preference were measured using a standard TBC paradigm as previously described (Bahi 2016; Bahi et al. 2016; Bahi and Dreyer 2012, 2014). In 


\section{a}

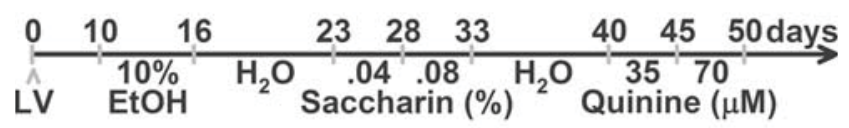
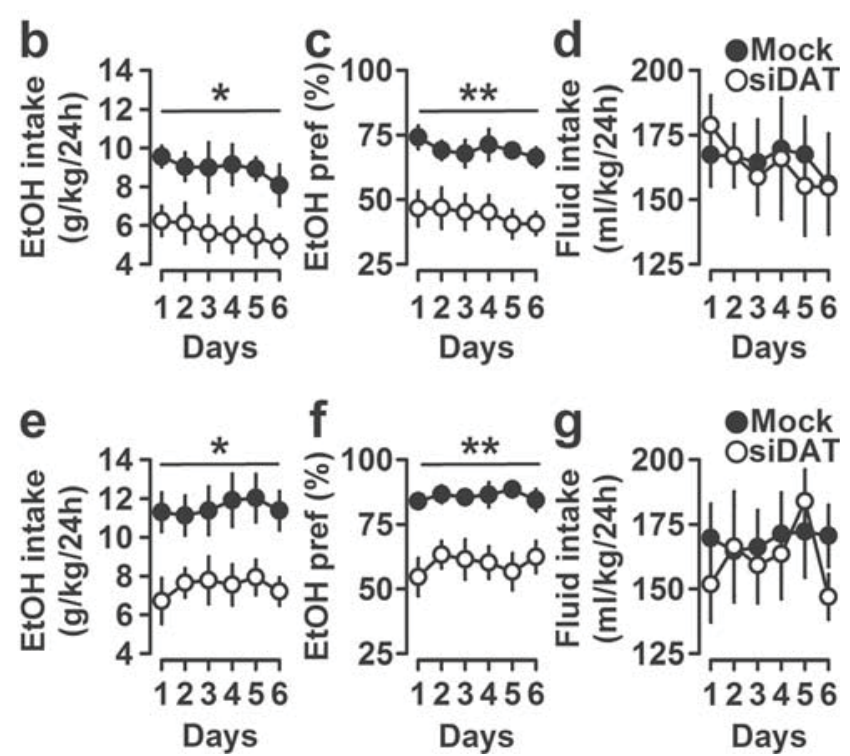

Fig. 1 Effect of DAT knockdown in males and females on ethanol consumption, preference, and total fluid intake after during a 24-h TBC test. a Summary of the experimental procedure. The data are expressed as mean \pm SEM for $\mathbf{b}$ ethanol consumption, $\mathbf{c}$ ethanol preference, $\mathbf{d}$ total fluid intake in males, $\mathbf{e}$ ethanol consumption, $\mathbf{f}$ ethanol preference, and $\mathbf{g}$ total fluid intake in females. ${ }^{*} p<0.01$ and $* * p<0.001$ indicate significant differences between mock and siDAT. $n=9-11$

brief, 10 days post surgery/viral injection, mice were exposed to a 6-day continued access $(24 \mathrm{~h} /$ day) TBC, using $10 \mathrm{~mL}$ pipettes fitted with stainless drinking spouts (one containing water and the other one containing $10 \%$ ethanol). The position of the pipettes (left or right) was changed every other day to avoid side bias. Throughout the experiment, evaporation/ spillage estimates were calculated daily from two pipettes placed in an empty cage. Every day, water and ethanol intakes were measured, and ethanol consumed ( $\mathrm{g} / \mathrm{kg}$ body weight/ $24 \mathrm{~h}$ ) was calculated for each mouse after the volumes were corrected for any spillage. Fluid intakes in grams were converted to milliliters with the assumption that for water $1 \mathrm{~mL}=$ $1 \mathrm{~g}$, and for $10 \%$ ethanol $1 \mathrm{~mL}=0.0789 \mathrm{~g}$. The ethanol preference was calculated as volume of ethanol consumed per total volume of water plus ethanol consumed. Total fluid intake was calculated and expressed as volume of water plus ethanol consumed per kilogram of body weight per day ( $\mathrm{ml} /$ $\mathrm{kg} /$ day). The values for ethanol consumption, preference, and the total fluid intake were averaged across the 6-day period.

As displayed in the experimental timeline (Fig. 1a), 1 week after the ethanol self-administration procedure, the same mice were tested for saccharin (0.04 and $0.08 \%)$ and quinine (35 and $70 \mu \mathrm{M}$ ) intake and preference using the same TBC protocol. The aim is to assess whether the decreased ethanol consumption and preference observed in siDAT-injected mice may be due to the pharmacological effects of ethanol because differential taste reactivity may affect ethanol consumption and preference. For both tastants, each concentration was offered for 5 days with the low concentration being presented first, followed by the higher concentration and with bottle position changed daily to control for side preference. Fluid intake (water, saccharin, or quinine) was measured every $24 \mathrm{~h}$, and body weights were recorded every 5 days throughout the whole study. As for ethanol, tastant intakes and total fluid intakes were corrected for body weight of the subject.

\section{Blood ethanol concentrations and alcohol elimination rate}

Ethanol elimination rate was determined to estimate whether DAT knockdown in the Nacc altered ethanol pharmacokinetics. An ethanol dose of $1.2 \mathrm{~g} / \mathrm{kg}$ was intraperitoneally injected. Approximately $50 \mu \mathrm{L}$ of tail blood samples were collected at 1,2 , and $3 \mathrm{~h}$ after injection, and plasma samples were spun down and stored at $-20{ }^{\circ} \mathrm{C}$ until further analysis. Plasma alcohol concentrations in milligrams per deciliter were measured using an Ethanol Colorimetric Assay Kit (BioVision Research Products, CA, USA) according to the instructions of the manufacturer and as we described previously (Al Ameri et al. 2014; Bahi et al. 2013, 2014). The area under the blood ethanol concentration-time curve (AUC) between 1 and $3 \mathrm{~h}$ was determined for each group.

\section{Total RNA isolation and quantitative RT-PCR analysis}

The entire accumbal tissue from mice injected with virus was freshly dissected and immediately processed individually for total RNA extraction using TRIzol according to the manufacturer's protocol. To verify DAT mRNA knockdown, singlestranded cDNA was synthesized from total RNA using the SuperScript III reverse transcriptase procedure. Following reverse transcription, quantitative RT-PCR was performed in triplicate using SyberGreen. The temperature cycling parameters consisted of initial denaturation at $95{ }^{\circ} \mathrm{C}$ for $4 \mathrm{~min}$ followed by 40 cycles of denaturation at $94^{\circ} \mathrm{C}$ for $30 \mathrm{~s}$ and annealing and extension at $60{ }^{\circ} \mathrm{C}$ for $45 \mathrm{~s}$. PCR for the control gene, cyclophilin, was run with the same cycling parameters. Normalization and relative expression analysis of DAT mRNA expression were done using the $2^{-\Delta \Delta \mathrm{Ct}}$ method with cyclophilin as the control because of its low variability between samples.

\section{Statistical analyses}

For statistical comparisons, the software package IBM SPSS Statistics 16.0 was used. Data were expressed as means \pm SEM. The data representing the effects of DAT knockdown 
on ethanol intake and preference were analyzed using a $2 \times$ $2 \times 6$ three-way analysis of variance (ANOVA) repeatedmeasure with virus (mock vs. siDAT) and sex (males vs. females) as the between-subject variable and day as the withinsubject variable. The data representing the effects of DAT knockdown on tastants' intake and preference were analyzed using a $2 \times 2 \times 2 \times 5$ four-way ANOVA repeated measures with virus, sex, and concentration as the between-subject variables and day as the within-subject variable. The data representing the effects of DAT knockdown on mRNA expression and the AUC for BECs were analyzed using a $2 \times 2$ two-way ANOVA with virus and sex as the between-subject variables. The data representing the effects of DAT knockdown on BECs were analyzed using a $2 \times 2 \times 3$ three-way ANOVA repeated measures with virus and sex as the between-subject variables and time as the within-subject variable. A series of post hoc correlations between levels of DAT mRNA and expression of ethanol-related behaviors were performed, using separate linear regressions (Pearson test), in order to provide further insight how changes in DAT mRNA expression may contribute to alterations in ethanol-related behaviors. The relationship is expressed as the correlation coefficient $(r)$. Bonferroni post hoc test was used when comparing among means, and all $p$ values less than 0.05 were considered statistically significant.

\section{Results}

\section{DAT knockdown decreased voluntary ethanol consumption and preference}

To determine whether reduced DAT expression would affect ethanol intake and preference, mice were injected bilaterally with siDAT or mock into the Nacc and then tested using the TBC procedure.

Ethanol consumption During the 6-day period, alcohol intake was stable in both males $\left(F_{(5,90)}=0.562, p=0.729\right.$; Fig. 1b) and females $\left(F_{(5,95)}=0.196, p=0.963\right.$; Fig. 1e). However, DAT knockdown decreased ethanol consumption in both sex groups $\left(F_{(1,18)}=26.884, p<0.0001\right.$; Fig. 1b) $\left(F_{(1,19)}=59.407, p<0.0001\right.$; Fig. 1e), respectively. When the data from both males and females were pooled and analyzed, the $2 \times 2 \times 6$ three-way ANOVA test indicated that, indeed, there was no significant effect of time (main effect of day: $\left.F_{(5,195)}=0.175, p=0.972\right)$. Yet, females consumed more ethanol than males (main effect of sex: $F_{(1,37)}=$ $28.661, p<0.0001)$. Interestingly, mice infected with siDAT exhibited significantly decreased ethanol consumption compared with control mice (main effect of virus: $F_{(1}$, $37)=79.947, p<0.0001)$. However, the sex $\times$ virus $\left(F_{(1}\right.$, $37)=0.802, p=0.367)$ and the sex $\times$ virus $\times$ day $\left(F_{(5,}\right.$
185) $=0.036, p=0.999$ ) interactions were not found to be significant. The results of the homogeneity by Levene test showed a homogeneous data $\left(F_{(3,37)}=2.306, p=0.093\right)$.

Ethanol preference Similarly, when data were expressed as a preference measure (volume of ethanol/total volume consumed), the results showed a stable ethanol preference for both males $\left(F_{(5,90)}=0.437, p=0.822\right.$; Fig. 1c) and females $\left(F_{(5,95)}=0.274, p=0.926\right.$; Fig. $\left.1 \mathrm{f}\right)$. However, ethanol preference was significantly decreased following DAT knockdown in both sex groups $\left(F_{(1,18)}=31.409, p<0.0001\right.$; Fig. $\left.1 \mathrm{c}\right)\left(F_{(1,}\right.$ 19) $=47.561, p<0.0001$; Fig. $1 \mathrm{f})$, respectively. The $2 \times 2 \times 6$ three-way ANOVA test between groups showed that ethanol preference was stable across the 6-day period test (main effect of day: $\left.F_{(5,185)}=0.195, p=0.964\right)$. However, females had more preference than males (main effect of sex: $F_{(1,37)}=$ $29.432, p<0.0001$ ), and that, compared to mock, siDAT injection decreased ethanol preference (main effect of virus: $F_{(1}$, $37)=76.711, p<0.0001)$. The sex $\times$ virus $\left(F_{(1,37)}=0.014, p=\right.$ $0.906)$ and the sex $\times$ virus $\times$ day $\left(F_{(5,185)}=0.051, p=0.998\right)$ interactions were not found to be significant. The Levene test applied to assess the equality of variances was not found to be significant $\left(F_{(3,37)}=0.211, p=0.888\right)$.

Total fluid intake Finally, the total volume of fluid consumed was not affected by time neither in males $\left(F_{(5,90)}=0.321, p=\right.$ 0.899 ; Fig. 1d) nor in females $\left(F_{(5,95)}=0.394, p=0.852\right.$; Fig. $1 \mathrm{~g})$. Also, viral injection had no effect on the amount of fluid consumed in both sex groups $\left(F_{(1,18)}=0.030, p=0.864\right.$; Fig. 1d) $\left(F_{(1,19)}=0.722, p=0.406\right.$; Fig. $\left.1 \mathrm{~g}\right)$, respectively. The three-way ANOVA, on pooled data from both males and females, revealed that neither sex $\left(F_{(1,37)}=0.031, p=0.862\right)$ nor virus $\left(F_{(1,37)}=0.439, p=0.511\right)$ affected the total fluid intake. Consequently, the sex $\times$ virus $\left(F_{(1,37)}=0.151, p=\right.$ $0.700)$ and the sex $\times$ virus $\times$ day $\left(F_{(5,185)}=0.370, p=\right.$ 0.868 ) interactions were not found to be significant (Levene test: $\left.F_{(3,37)}=2.071, p=0.121\right)$. The Levene test showed equality of variances $\left(F_{(3,37)}=2.071, p=0.121\right)$.

Taken together, these findings suggest that decreased ethanol consumption following DAT knockdown in the Nacc was not caused by an overall decrease in the total amount of fluid consumed.

\section{DAT knockdown in the Nacc did not affect saccharin's consumption and preference}

Because ethanol might affect taste responses, it is critical to examine the sensitivity of both experimental groups to sweet (saccharin) and bitter (quinine) solutions' tastes to determine whether differences in alcohol consumption are secondary to changes in taste. Therefore, 1 week after completion of the ethanol intake test, the same mice were examined for taste preference using a TBC paradigm. For this purpose, mice 
could drink either water or an ascending series of saccharin $(0.04$ and $0.08 \%$ ) or quinine ( 35 or $70 \mu \mathrm{M})$ concentrations.

Saccharin consumption The ANOVA analysis revealed that neither in males $\left(F_{(4,144)}=1.432, p=0.226\right.$; Fig. $\left.2 \mathrm{a}\right)$ nor in females $\left(F_{(4,152)}=0.787, p=0.535\right.$; Fig. $\left.2 c\right)$ time affected saccharin intake. The secondary analysis of pooled data using a $2 \times 2 \times 2 \times 5$ four-way ANOVA test indicated that there was no significant effect of time in all outcome measures (main effect of day: $\left.F_{(4,296)}=1.037, p=0.389\right)$. Also, both mockand siDAT-injected mice escalated their saccharin intake when presented tastant in an unrestricted fashion as a choice against water in the TBC test (main effect of concentration: $F_{(1,74)}=$ 687.357, $p<0.0001$ ) with large increases in saccharin consumption being observed when the higher concentration of saccharin $(0.08 \%)$ was presented. However, neither sex $\left(F_{(1}\right.$, $\left.{ }_{74)}=0.028, p=0.868\right)$ nor virus $\left(F_{(1,74)}=0.077, p=0.783\right)$ affected saccharin intake. Thus, the sex $\times$ virus $\times$ concentration $\left(F_{(1,74)}=0.439, p=0.510\right)$ and the sex $\times$ virus $\times$ concentration $\times$ day $\left(F_{(4,296)}=0.177, p=0.950\right)$ interactions were not found to be significant. The Levene test used to assess equality of the residual variances across both groups was not found to be significant $\left(F_{(7,74)}=0.477, p=0.848\right)$.

Saccharin preference As stated above, we pooled both sex groups' data, and the analysis using a $2 \times 2 \times 2 \times 5$ four-way ANOVA test indicated that time did not affect saccharin preference (main effect of day: $F_{(4,296)}=0.294, p=0.882$ ). Although there was an increased preference for the highly
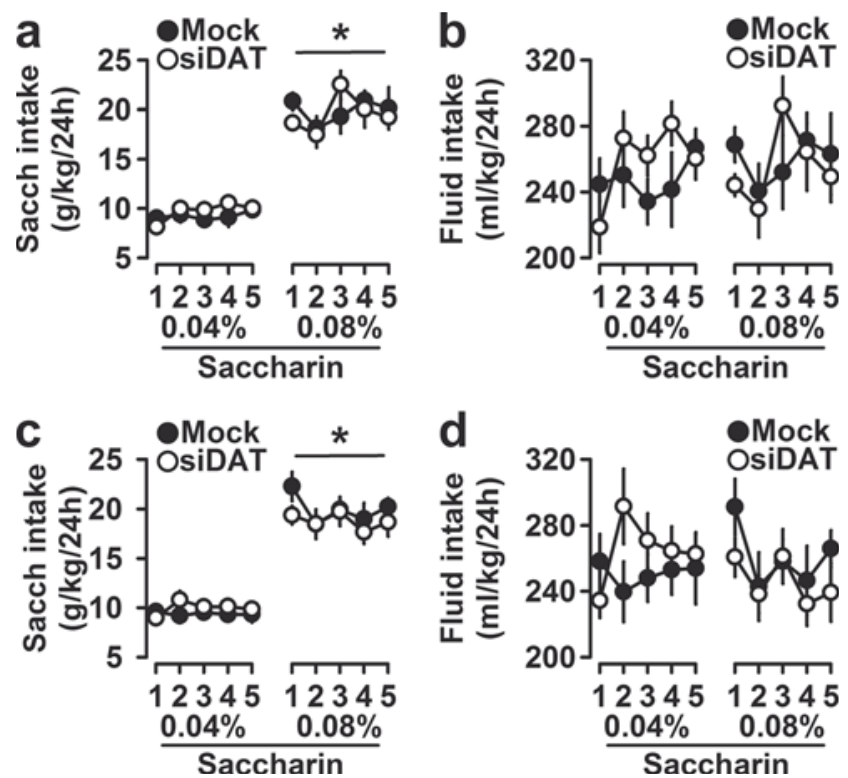

Fig. 2 Effect of DAT knockdown in males and females on saccharin consumption and total fluid intake after during a $24-\mathrm{h}$ TBC test. The data are expressed as mean \pm SEM for a saccharin consumption, $\mathbf{b}$ total fluid intake in males, $\mathbf{c}$ saccharin consumption, and $\mathbf{d}$ total fluid intake in females. $* p<0.0001$ indicates significant differences between 0.04 and $0.08 \% . n=9-11$ concentrated saccharin (main effect of concentration: $F_{(1}$, 74) $=18.648, p<0.001$ ), no differences in the sweetener preference were found between mock- and siDAT-injected mice $\left(F_{(1,74)}=0.011, p=0.915\right)$ or between males and females $\left(F_{(1,}\right.$ 74) $=0.001, p=0.982)$. Also, neither the sex $\times$ virus $\times$ concentration $\left(F_{(1,74)}=0.117, p=0.734\right)$ nor the sex $\times$ virus $\times$ concentration $\times$ day $\left(F_{(4,296)}=0.522, p=0.720\right)$ interaction was found to be significant (data not shown). The Levene homogeneity of variances test was not significant $\left(F_{(7,74)}=1.217\right.$, $p=0.304)$.

Total fluid intake Finally, time did not affect the amount of fluid consumed by males $\left(F_{(4,144)}=1.173, p=0.325 ;\right.$ Fig. 2 b) or females $\left(F_{(4,152)}=0.404, p=0.806\right.$; Fig. $\left.2 \mathrm{~d}\right)$. When we pooled the data from both sexes, the four-way ANOVA with repeated measures indicated that none of the factors affected the total amount of fluid intake: (main effect of day: $F_{(4,296)}=$ $0.462, p=0.764)$; (main effect of concentration: $F_{(1,74)}=$ $0.001, p=0.983$ ); (main effect of sex: $F_{(1,74)}=0.002, p=$ 0.963 ); (main effect of virus: $F_{(1,74)}=0.116, p=0.734$ ). Therefore, the interaction between the four factors was not significant $\left(F_{(4,296)}=0.001, p=0.977\right)$. The change in variance assessed using Levene homogeneity of variance test was not significant $\left(F_{(7,74)}=1.214, p=0.306\right)$.

\section{DAT knockdown in the Nacc did not affect quinine consumption and preference}

One week after completion of the saccharin intake experiment, the same mice had access to either tap water or an ascending series of quinine concentrations (35 and $70 \mu \mathrm{M})$.

Quinine consumption During the 5-day period, quinine intake was stable in both males $\left(F_{(4,144)}=0.247, p=0.911\right.$; Fig. 3a) and females $\left(F_{(4,152)}=0.443, p=0.778\right.$; Fig. $\left.3 c\right)$. The $2 \times 2 \times$ $2 \times 5$ four-way ANOVA test, using pooled results from males and females, demonstrated that time had no effect on quinine intake (main effect of day: $F_{(4,296)}=0.473, p=0.756$ ). Although the four experimental groups consumed more quinine from the $70-\mu \mathrm{M}$ solution (main effect of concentration: $\left.F_{(1,74)}=194.919, p<0.0001\right)$, neither $\operatorname{sex}\left(F_{(1,74)}=0.148\right.$, $p=0.702)$ nor virus $\left(F_{(1,74)}=0.001, p=0.984\right)$ affected quinine intake. Thus, the sex $\times$ virus $\times$ concentration $\left(F_{(1,74)}=\right.$ $0.053, p=0.819)$ and the sex $\times$ virus $\times$ concentration $\times$ day $\left(F_{(4,296)}=0.506, p=0.732\right)$ interactions were not found to be significant. Equality or homogeneity of variances of the groups compared, done by Levene test, was not significant $\left(F_{(7,74)}=0.275, p=0.916\right)$.

Quinine preference The $2 \times 2 \times 2 \times 5$ four-way ANOVA test, using the pooled data from both sexes, indicated that time did not affect quinine preference (main effect of day: $F_{(4,296)}=$ $0.078, p=0.989)$. In addition, none of the other factors 

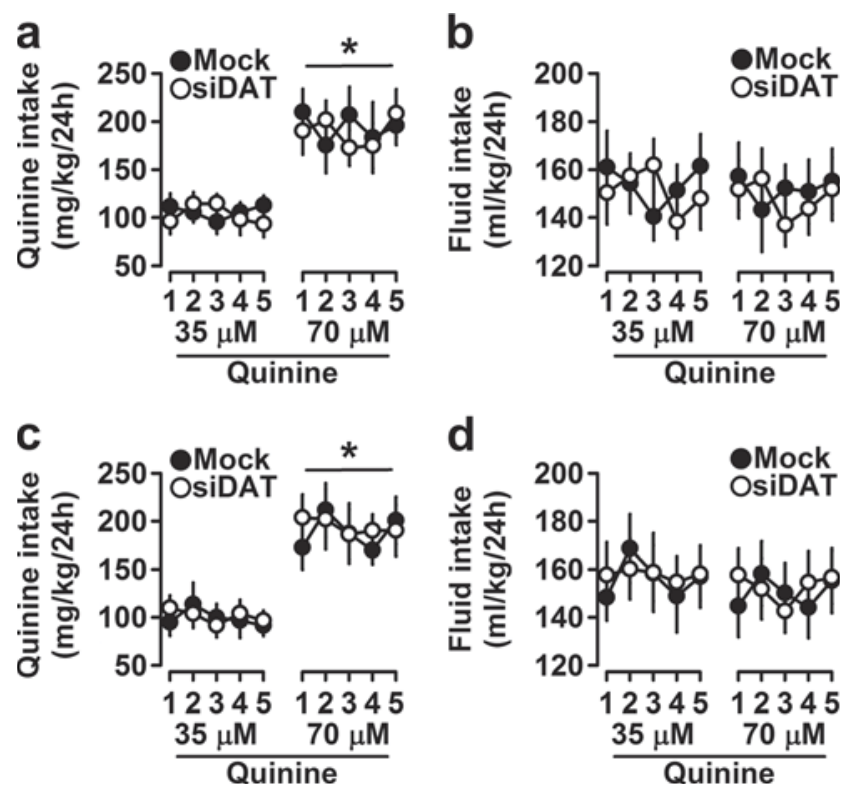

Fig. 3 Effect of DAT knockdown in males and females on quinine consumption and total fluid intake after during a 24-h TBC test. The data are expressed as mean \pm SEM for a quinine consumption, $\mathbf{b}$ total fluid intake in males, $\mathbf{c}$ quinine consumption, and $\mathbf{d}$ total fluid intake in females. $* p<0.001$ indicates significant differences between 35 and $70 \mu \mathrm{M} . n=9-11$

affected quinine preference: (main effect of concentration: $F_{(1}$, $\left.{ }_{74)}=0.625, p=0.432\right)$; (main effect of sex: $F_{(1,74)}=0.151$, $p=0.699$ ); (main effect of virus: $F_{(1,74)}=0.001, p=0.993$ ). Therefore, the interaction between the four factors was not significant $\left(F_{(4,296)}=0.001, p=0.977\right)$. Therefore, the sex $\times$ virus $\times$ concentration $\left(F_{(1,74)}=0.008, p=0.929\right)$ and the sex $\times$ virus $\times$ concentration $\times$ day $\left(F_{(4,296)}=0.077, p=0.989\right)$ interactions were not found to be significant (data not shown). Evaluation of results from the Levene test of equality of variances showed no significant difference $\left(F_{(7,74)}=1.814, p=\right.$ 0.097).

Total fluid intake Finally, when analyzed separately, time did not affect the amount of fluid consumed by males $\left(F_{(4,144)}=\right.$ $0.449, p=0.773$; Fig. $3 b)$ or females $\left(F_{(4,152)}=0.356, p=\right.$ 0.740; Fig. $3 d$ ). Also, the $2 \times 2 \times 2 \times 5$ four-way ANOVA test, conducted on the pooled data, showed that none of the factors affected the total amount of fluid intake: (main effect of day: $\left.F_{(4,296)}=0.610, p=0.655\right)$; (main effect of concentration: $F_{(1 \text {, }}$ ${ }_{74)}=1.016, p=0.317$ ); (main effect of sex: $F_{(1,74)}=0.652$, $p=0.422$ ); (main effect of virus: $F_{(1,74)}=0.021, p=0.885$ ). Also, the interaction between the four factors was not found to be significant $\left(F_{(4,296)}=0.203, p=0.937\right)$. In estimating the homogeneity of the average values, the Levene test was not significant $\left(F_{(7,74)}=0.663, p=0.702\right)$.

Taken together, these results suggest that it is, therefore, unlikely that the effects of siDAT injection into the Nacc on voluntary ethanol consumption and preference result from general alterations in sensory abilities or palatability.

\section{siDAT reduced DAT mRNA levels in the Nacc}

To determine the persistence of infection in the Nacc, mice were injected bilaterally with $0.5 \mu \mathrm{L}$ of siDAT and examined for mRNA expression after completion of the behavioral experiment using quantitative RT-PCR and the results are displayed in Table 1 . The Levene test used to assess variances was not significant $\left(F_{(3,37)}=1.124, p=0.352\right)$. However, the two-way ANOVA revealed that in the Nacc, DAT mRNA levels were decreased by approximately $60 \%$, indicating that the siDAT was functional (main effect of virus: $\left(F_{(1,37)}=\right.$ $31.144, p<0.0001)$, regardless of $\operatorname{sex}\left(F_{(1,37)}=0.196, p=\right.$ $0.661)$. Also, the virus $\times$ sex interaction was not significant $\left(F_{(1,37)}=0.193, p=0.663\right)$.

These results suggest that we could consistently infect the Nacc, the infection lasted for the time required to complete behavioral experiments, and siDAT was effective in downregulating DAT expression in infected accumbal neurons in vivo.

\section{DAT knockdown in the Nacc did not affect BECs}

Because differences in ethanol metabolism produced by the treatments might drive differences in voluntary ethanol intake and preference, we examined the time course of BECs after a $1.2 \mathrm{~g} / \mathrm{kg}$ i.p. injection in the four experimental groups, and BECs from males and females were analyzed separately. In males, and after testing the normality of the data through the Levene test for the three time points $\left(1 \mathrm{~h}: F_{(1,18)}=2.394, p=\right.$ $0.139 ; 2 \mathrm{~h}: F_{(1,18)}=0.009, p=0.924$; and $3 \mathrm{~h}: F_{(1,18)}=0.003$, $p=0.955)$, the one-way ANOVA with repeated measures revealed that plasma ethanol concentrations decreased in a timedependent manner (main effect of time: $F_{(2,36)}=128.830$, $p<0.0001)$. However, we found no differences between mock- and siDAT-injected mice with respect to blood ethanol elimination rate at any time point (main effect of virus: $F_{(1}$, $\left.{ }_{18)}=0.001, p=0.977\right)$, and the virus $\times$ time interaction was not found to be significant $\left(F_{(2,36)}=1.420, p=0.255\right)$ (Fig. 4a). Similarly, in females, BECs decreased overtime $\left(F_{(2,38)}=97.044, p<0.0001\right)$. However, neither DAT knockdown $\left(F_{(1,19)}=0.056, p=0.816\right)$ nor the interaction $\left(F_{(2}\right.$, $38)=0.455, p=0.638$ ) was found to be significant (Fig. $4 \mathrm{~b}$ ). Also, the Levene test for homogeneity of variance analysis

Table 1 Effect of DAT knockdown in males and females on DAT mRNA levels. The data are expressed as mean \pm SEM for relative DAT mRNA expression (arbitrary units) as measured by quantitative RT-PCR. $n=9-11$

\begin{tabular}{lll}
\hline & Mock & siDAT \\
\hline Males & $1.000 \pm 0.124$ & $0.443 \pm 0.090^{*}$ \\
Females & $1.000 \pm 0.139$ & $0.348 \pm 0.078^{*}$ \\
\hline
\end{tabular}

${ }^{*} p<0.0001$ indicates significant differences between mock and siDAT 

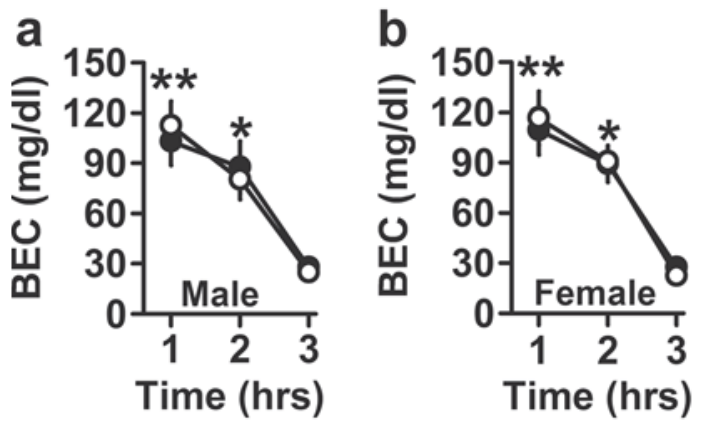

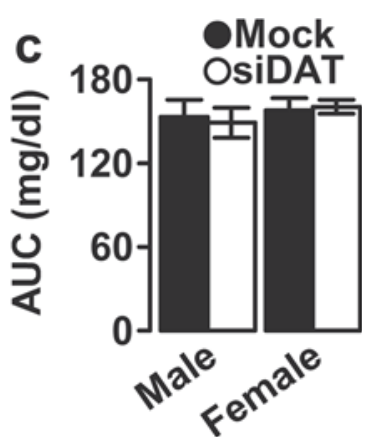

following a $1.2-\mathrm{g} / \mathrm{kg}$ ethanol challenge in a male and $\mathbf{b}$ female C57BL/ $6 \mathrm{~J}$ mice. $\mathrm{c}$ Area under the curve (AUC) for BECs in male and female mice. ${ }^{*} p<0.001$ for 2 vs. 3 h and ${ }^{*} p<0.0001$ for 1 vs. 3 h. $n=9-11$ was not found to be significant $\left(1 \mathrm{~h}: F_{(1,19)}=0.095, p=0.762\right.$; $2 \mathrm{~h}: F_{(1,18)}=0.007, p=0.933$; and $3 \mathrm{~h}: F_{(1,18)}=1.551, p=$ $0.228)$. The BEC data for both males and females were combined and analyzed using two-way ANOVA with repeated measures. The statistical analysis indicated that, as expected, there was a significant effect of time $\left(F_{(2,74)}=215.483\right.$, $p<0.0001)$. However, the main effects of virus $\left(F_{(1,37)}=\right.$ $0.012, p=0.914)$, sex $\left(F_{(1,37)}=0.593, p=0.446\right)$, or the time $\times \operatorname{sex} \times$ virus interaction $\left(F_{(2,74)}=0.282, p=0.755\right)$ were not found to be significant. Furthermore, and as displayed in Fig. $4 \mathrm{c}$, the area under the curve (AUC) of the blood ethanol levels of the four experimental groups was analyzed and the Levene test used to assess variances was not significant $\left(F_{(3,37)}=\right.$ $1.454, p=0.243)$. Also, the two-way ANOVA indicated that neither the virus $\left(F_{(1,37)}=0.006, p=0.939\right)$ nor sex $\left(F_{(1,37)}=\right.$
$0.728, p=0.399)$ affected the AUC. Also, the interaction was not significant $\left(F_{(1,37)}=0.123, p=0.728\right)$.

Taken together, the changes in ethanol-related behaviors following DAT knockdown did not result from potential differences in clearance of alcohol.

\section{Significant correlation between DAT mRNA with ethanol-related behaviors}

Using the data of DAT mRNA obtained from the mock- and siDAT-injected mice, a simple linear regression (Pearson) analysis was performed to examine the correlation between DAT transcription levels and ethanol consumption and preference in both males and females, and the scatter plots are provided in Fig. 5. Post hoc linear regressions revealed that differences in
Fig. 5 Pearson correlations in males and females for ethanolrelated behaviors. The data represent simple scatter regression between accumbal DAT mRNA levels (arbitrary units) in mockand siDAT-injected mice with a ethanol consumption, $\mathbf{b}$ ethanol preference, and $\mathbf{c}$ total fluid intake in males and with $\mathbf{d}$ ethanol consumption, e ethanol preference, and $\mathbf{f}$ total fluid intake in females
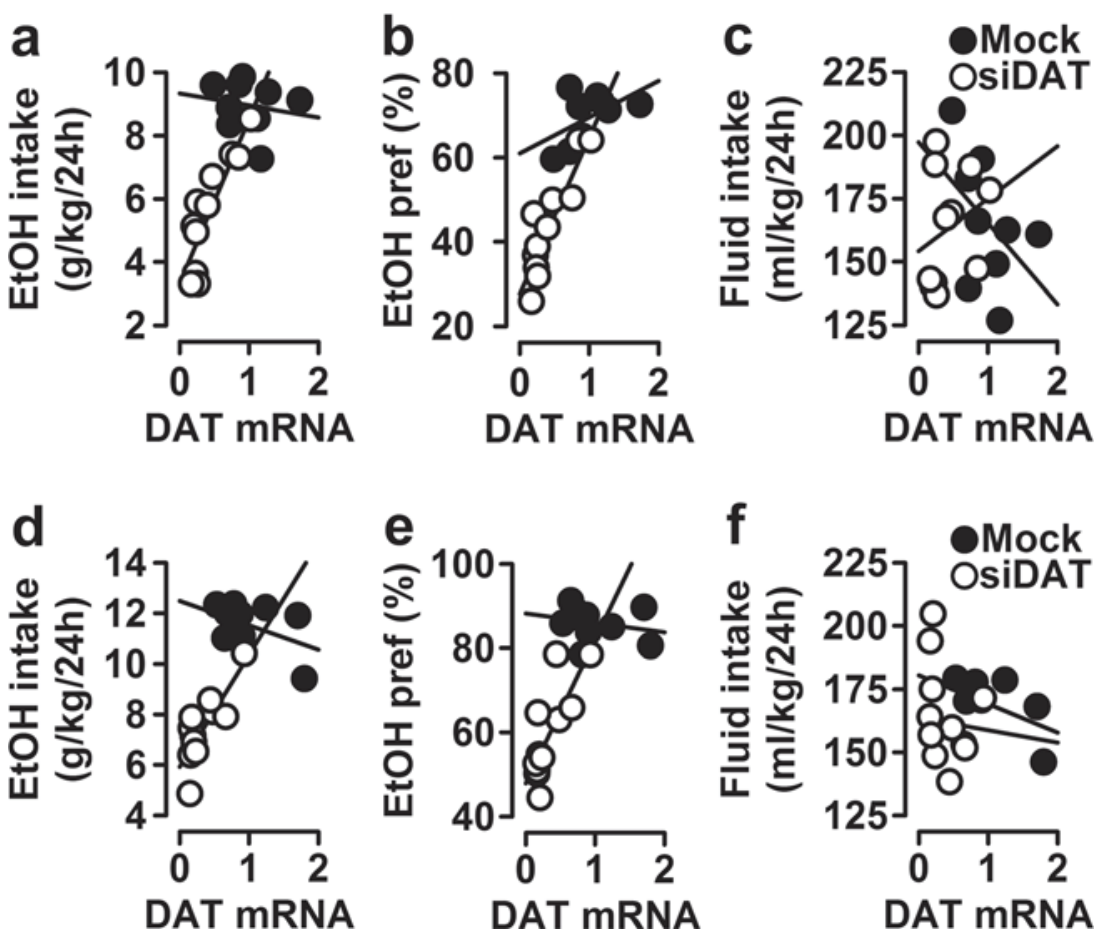
DAT mRNA levels within the Nacc accounted for many of the behavioral alterations exhibited by the mice.

In males, and as depicted in Fig. 5a, Pearson correlation coefficients revealed a positive correlation between DAT mRNA levels with ethanol consumption $\left(r=0.746 ; F_{(1}\right.$, $\left.{ }_{18)}=22.656, p=0.00014\right)$. However, post hoc linear regression analysis indicated that this effect was mainly driven by the siDAT-injected $(r=0.882, p=0.0003)$, but not mockinjected mice $(r=0.173, p=0.657)$. Similarly, DAT mRNA was positively correlated with ethanol preference $(r=0.845$; $\left.F_{(1,18)}=44.972, p<0.0001\right)$. Again, the correlation was only significant in the $\operatorname{siDAT}(r=0.894, p=0.0002)$, but not in the mock group ( $r=0.527, p=0.144)$ (Fig. 5b). Finally, and as shown in Fig. 5c, DAT mRNA did not correlate with the amount of total fluid consumed $\left(r=-0.061 ; F_{(1,18)}=0.067\right.$, $p=0.799)$.

In females, the Pearson test revealed that there was a positive correlation between DAT mRNA levels with ethanol intake $\left(r=0.659 ; F_{(1,19)}=14.562, p=0.001\right)$, that was driven by the siDAT-injected mice $(r=0.809, p=0.003)$, but not the mock controls $(r=0.463, p=0.177)$ (Fig. $5 \mathrm{~d})$. In the same way, DAT mRNA correlated positively with ethanol preference in female mice $\left(r=0.709 ; F_{(1,19)}=19.181, p<0.0001\right)$. The effects on correlation during this test were mainly driven by the siDAT-injected mice $(r=0.777, p=0.005)$, but not the mock controls $(r=0.239, p=0.507)$ (Fig. 5e). Interestingly, and as displayed in Fig. 5f, no significant correlation between DAT mRNA and total fluid intake was found $\left(r=0.007 ; F_{(1}\right.$, 19) $=0.001, p=0.974)$.

The results implied that, regardless of the sex of the animals, ethanol consumption and preference were significantly associated with accumbal DAT mRNA expression. That is, all the proposed hypotheses were supported based on Pearson correlation coefficients.

\section{No correlation between DAT mRNA with tastants' consumption and preference}

We also conducted Pearson correlation coefficients to examine the relationships between DAT mRNA and tastants' intake and the results are depicted in Fig. 6.

In males, we found that the linear relationships between DAT mRNA and saccharin consumption were not significant for both the $0.04 \%\left(r=-0.139 ; F_{(1,18)}=0.355, p=0.559\right.$; Fig. 6a) and the $0.08 \%\left(r=-0.066 ; F_{(1,18)}=0.079, p=\right.$ 0.782 ; Fig. $6 b)$ solutions. Similarly, Pearson correlation coefficients indicated that the association between saccharin preference and DAT mRNA was not significant for neither of the solutions $\left(0.04 \%: r=-0.077 ; F_{(1,18)}=0.107, p=0.747\right.$; Suppl. Fig. 1a and 0.08\%: $r=0.174 ; F_{(1,18)}=0.559, p=$ 0.464; Suppl. Fig. 1b). Finally, for the total amount of fluid consumed, the Pearson correlation coefficients for the DAT mRNA obtained with the 0.04 and $0.08 \%$ solutions were not significant: $\left(r=-0.137 ; F_{(1,18)}=0.344, p=0.565\right.$; Suppl. Fig. 1c) and $\left(r=-0.094 ; F_{(1,18)}=0.161, p=0.693\right.$; Suppl. Fig. 1d), respectively. Furthermore, according to the Pearson correlation coefficient analyses, quinine consumption demonstrated no correlation with DAT mRNA for both solutions (35 $\mu \mathrm{M}: r=0.015 ; F_{(1,18)}=0.004, p=0.951$; Fig. $6 \mathrm{c}$ and $70 \mu \mathrm{M}: r=0.295 ; F_{(1,18)}=1.709, p=0.208$; Fig. $\left.6 \mathrm{~d}\right)$. For quinine preference, the Pearson correlation coefficients were $\left(r=0.125 ; F_{(1,18)}=0.287, p=0.599\right.$; Suppl. Fig. $\left.2 \mathrm{a}\right)$ for the $35-\mu \mathrm{M}$ quinine solution and $\left(r=0.380 ; F_{(1,18)}=1.180, p=\right.$ 0.187 ; Suppl. Fig. $2 b$ ) for the $70-\mu \mathrm{M}$ quinine solution, suggesting no correlation between DAT mRNA and quinine preference. For total fluid intake, a Pearson correlation was conducted to test the relationship between DAT mRNA and behavior response. No significant relationships were observed for the $35-\mu \mathrm{M}\left(r=-0.133 ; F_{(1,18)}=0.326, p=0.575\right.$; Suppl.
Fig. 6 Pearson correlations in males and females for tastantrelated behaviors. The data represent simple scatter regression between accumbal DAT mRNA levels (arbitrary units) in mockand siDAT-injected mice with a $0.04 \%$ saccharin consumption, $\mathbf{b}$ $0.08 \%$ saccharin consumption, $\mathbf{c}$ $35 \mu \mathrm{M}$ quinine consumption, and d $70 \mu \mathrm{M}$ quinine consumption in males and with e $0.04 \%$ saccharin consumption, f $0.08 \%$ saccharin consumption, g $35 \mu \mathrm{M}$ quinine consumption, and h $70 \mu \mathrm{M}$ quinine consumption in females
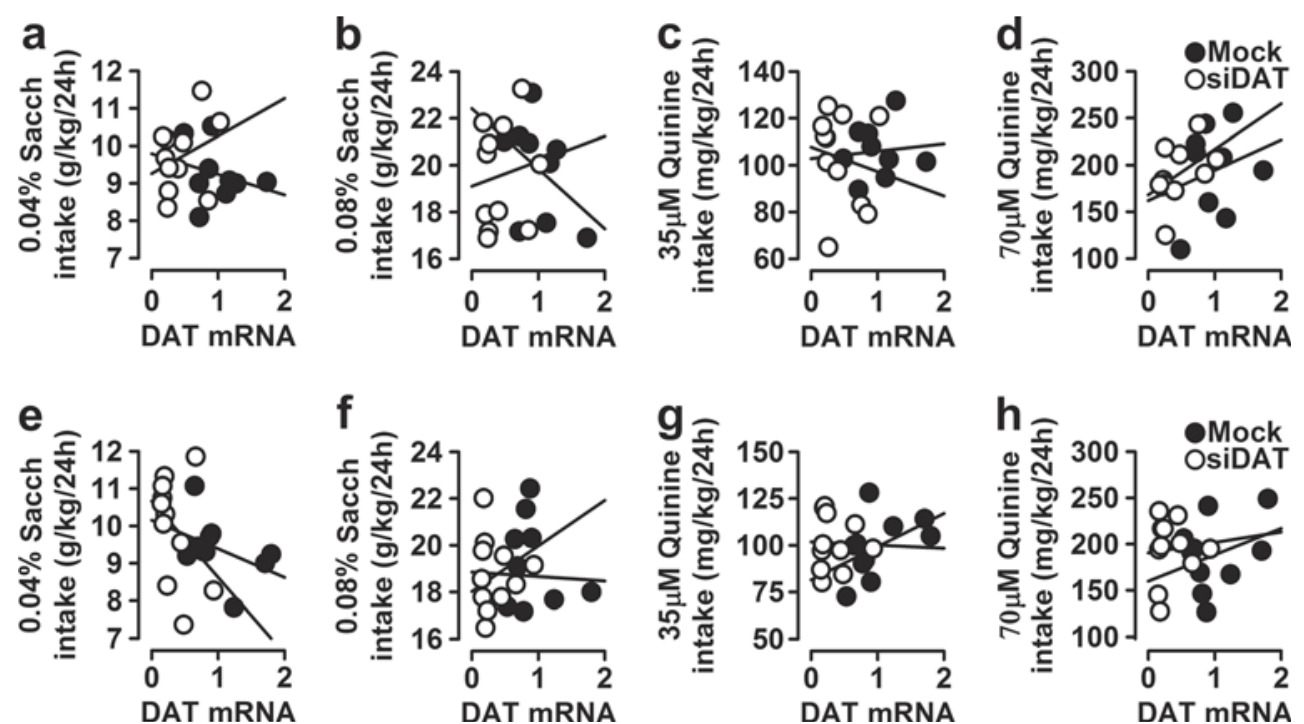
Fig. 2c) and the $70-\mu \mathrm{M}\left(r=-0.123 ; F_{(1,18)}=0.275, p=\right.$ 0.606; Suppl. Fig. 2d) quinine solution.

In females, the Pearson correlation coefficient between DAT mRNA and saccharin consumption from the $0.04 \%$ solution was $\left(r=-0.410 ; F_{(1,19)}=3.849, p=0.065\right.$; Fig. 6e), and with the $0.08 \%$ solution, it was $\left(r=0.341 ; F_{(1,19)}=\right.$ 2.507, $p=0.130$; Fig. 6f). Pearson correlation also showed no direct relationship between DAT mRNA and preference for the $0.04 \%\left(r=-0.131 ; F_{(1,19)}=0.330, p=0.572\right.$; Suppl. Fig. 1e) or the $0.08 \%\left(r=0.268 ; F_{(1,19)}=1.473, p=0.240\right.$; Suppl. Fig. 1f) saccharin solution. Lastly, Pearson correlations were calculated between DAT mRNA and total fluid intake, and the resulting correlation was not significant for both solutions $\left(0.04 \%: r=-0.430 ; F_{(1,19)}=4.311, p=0.052\right.$; Suppl. Fig. $1 \mathrm{~g}$ and $0.08 \%: r=0.316 ; F_{(1,19)}=2.111, p=0.163$; Suppl. Fig. 1h). Furthermore, according to Pearson correlation coefficient, it was observed that there is no significant relationship between DAT mRNA and quinine consumption from either of the solutions $\left(35 \mu \mathrm{M}: r=0.160 ; F_{(1,19)}=0.501, p=\right.$ 0.488 ; Fig. $6 \mathrm{~g}$ and $70 \mu \mathrm{M}: r=0.108 ; F_{(1,19)}=0.226, p=$ 0.640 ; Fig. 6h). Similarly, there was no statistically significant correlation between DAT mRNA expression and quinine preference for both solutions $\left(35 \mu \mathrm{M}: r=0.130 ; F_{(1,19)}=0.326\right.$, $p=0.575$; Suppl. Fig. 2e and $70 \mu \mathrm{M}: r=0.277 ; F_{(1,19)}=$ $1.575, p=0.225$; Suppl. Fig. 2f). Finally, the total amount of fluid consumed when the $35-$ and $70-\mu \mathrm{M}$ quinine solutions were presented was not affected by DAT mRNA levels according to the Pearson correlation analysis $\left(r=-0.191 ; F_{(1}\right.$, ${ }_{19)}=0.718, p=0.407$; Suppl. Fig. $2 \mathrm{~g}$ and $r=-0.173 ; F_{(1,}$ 19) $=0.585, p=0.454$; Suppl. Fig. $2 \mathrm{~h}$, respectively).

Overall, in both males and females, there was no significant relationship between accumbal DAT mRNA expression and tastants' intake and preference.

\section{No correlation between DAT mRNA expression with BECs}

To determine whether DAT mRNA expression was associated with BECs in both males and females, Pearson correlation coefficients were again obtained, and the results are depicted in Fig. 7 and Suppl. Fig. 3.

In males and as shown in Fig. 7a, the correlation between DAT mRNA and the AUC for the BECs was not significant $\left(r=-0.066 ; F_{(1,18)}=0.080, p=0.781\right)$. Also, DAT mRNA was not associated with BECs at any time point: (BECs @ $1 \mathrm{~h}: r=-0.063 ; F_{(1,18)}=0.071, p=0.793$; Suppl. Fig. 3a), (BECs @ $2 \mathrm{~h}: r=-0.057 ; F_{(1,18)}=0.059, p=0.811$; Suppl. Fig. 3b), and (BECs @ 3 h: $r=-0.042 ; F_{(1,18)}=0.032, p=$ 0.860; Suppl. Fig. 3c). Similarly, in females, the Pearson correlation did not indicate any relationship between DAT mRNA and the AUC for the BECs $\left(r=0.015 ; F_{(1,18)}=\right.$ $0.004, p=0.949$; Fig. 7b). In addition, DAT mRNA was not associated with BECs at any time point: (BECs @ $1 \mathrm{~h}: r=-$ 0.007; $F_{(1,18)}=0.001, p=0.977$; Suppl. Fig. 3d), (BECs @ 2 h: $r=-0.045 ; F_{(1,18)}=0.038, p=0.847$; Suppl. Fig. 3e), and (BECs @ 3 h: $r=0.298 ; F_{(1,18)}=1.853, p=0.189$; Suppl. Fig. 3f).

Taken together, regardless of sex, accumbal DAT mRNA alteration had no effect on BECs and alcohol metabolism.

\section{Discussion}

In this study, we explored the role of the accumbal DAT in relation to voluntary ethanol consumption and preference. DAT plays a significant role in ethanol-related behaviors, but its associated actions in the Nacc of adult male and female C57BL/6 mice are still to be determined. To fill this knowledge gap, an integrative approach of lentiviral-mediated gene transfer strategy (local DAT knockdown) and behavioral assays was used. In line with our hypothesis, we found that local DAT knockdown in the Nacc reduced voluntary ethanol consumption and preference in a standard TBC drinking test. However, we found no sex-specific differences in males and females. Also, we found a strong correlation between DAT mRNA expression in the Nacc and ethanol-related behaviors. Control experiments showed that DAT knockdown had no
Fig. 7 Pearson correlations in males and females for BECs. The data represent simple scatter regression between accumbal DAT mRNA levels (arbitrary units) in mock- and siDATinjected mice with AUC of BECs in $\mathbf{a}$ males and $\mathbf{b}$ females

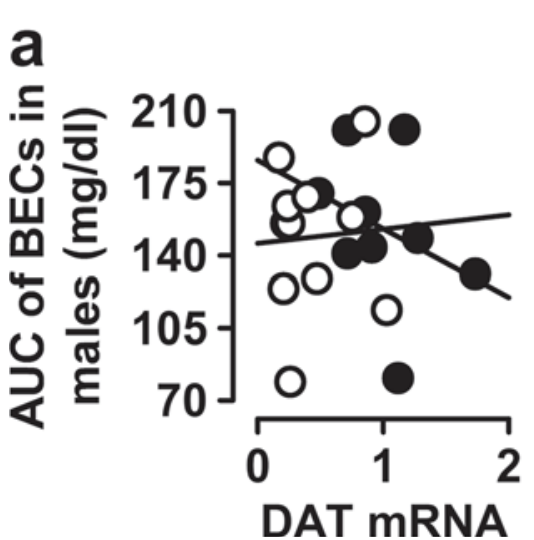


effects on saccharin and quinine intake and preference as well as ethanol metabolism.

Our findings are partially consistent with the previous report that ethanol consumption and preference were reduced in DAT KO females but not in males, despite altered taste preference for saccharin and quinine (Savelieva et al. 2002). They also agree with the phenotype of prodynorphin knockouts, which, compared to WT mice, showed that increased ethanol consumption and preference in a TBC paradigm were associated with higher DAT gene expression in the VTA and SN (Femenia and Manzanares 2012). Together, these data suggest that accumbal DAT signaling modulates ethanol consumption and preference in mice regardless of the animals' sex. However, our results do not agree with previous studies reporting that DAT deletion increased ethanol consumption. In detail, Hall and colleagues reported that ablation of DAT increased ethanol consumption in males but not in females, although female heterozygote mice exhibited higher ethanol preferences and there was a trend for female $\mathrm{KO}$ mice to drink less ethanol and to have lower preferences (Hall et al. 2003). The reasons for these discrepancies are not clear. Nevertheless, one can speculate that the different genetic backgrounds of the mice used in these studies could, at least in part, explain the disparate results. In fact, DAT KO mice from Hall and colleagues' study were maintained on a mixed C57/129sv background. Interestingly, it was found that inbred C57BL/6J mice showed greater ethanol preference and consumption than C57BL/6J × 129S4/SvJae F1 hybrids when ethanol was continuously available (Lim et al. 2012), which is in line with previous studies comparing ethanol intake in B6 and 129 mice (Bachmanov et al. 1996; Belknap et al. 1993; Yoneyama et al. 2008). Also, procedural differences are most likely to account for these disagreements, such as the concentrations of the ethanol solutions used in the studies (up to $32 \%$ in the study by Hall and colleagues). Finally, environmental stressors such as ambient odors, noise, and vibrations that might certainly vary between animal facilities could alter ethanol consumption, suggesting that test standardization should be a major concern for future research to reconciliate these findings. Furthermore, a possible pitfall when using constitutive DAT KO animals is that mice may present altered phenotypic responses due to compensatory mechanisms to cope with the total absence of DAT expression in dopaminergic structures. Therefore, developing and producing conditional DAT KO animals could certainly help overcome these limitations.

In both mock- and siDAT-injected mice, we observed that females consumed more ethanol than males which is consistent with previously published studies. In fact, several studies reported that, compared to males, female mice consumed more of a high-ethanol concentration solution $(10 \%)$ in a continuous access paradigm (Middaugh et al. 1999; Yoneyama et al. 2008). Also, female adenosine $\mathrm{A}_{2 \mathrm{~A}}$ receptor $\mathrm{KO}$ mice showed increased consumption of solutions containing 6 and $10 \%$ ethanol (Naassila et al. 2002). It should be emphasized that the decreased ethanol consumption observed following accumbal DAT knockdown was associated with a significant decrease in ethanol preference, with control animals regardless of sex, showing high-ethanol preference ratios (>50\%), which was expected because this phenotype is significantly associated to the genetic background. In fact, our data are in line with those of Yoneyama and colleagues showing that among the 22 inbred mouse strains tested, the C57BL/6J mice showed the highest preference for the $10 \%$ ethanol solution (approximately 90\%) (Yoneyama et al. 2008). Consequently, it is safe to speculate that the reduced ethanol preference observed in siDAT-injected mice was a clear indication of a low preference for the $10 \%$ ethanol solution over tap water.

Since it was originally introduced (Richter 1926), the TBC model has dominated studies of the neurobiology of alcohol drinking in rodents, and thus, a large body of literature exists using this procedure. Although this test can provide some very useful information about intensity, it is difficult to distinguish the intensity of the stimulus independent of its hedonic characteristics because it is the latter that drives the intake. In fact, Eylam and Spector found, using an operant-conditioning procedure, that the sodium chloride " $\mathrm{NaCl}$ " detection thresholds were lower than the concentration at which the same mice started to consistently avoid the stimulus in a standard TBS procedure (Eylam and Spector 2002). Therefore, even though mice could perceive low concentrations of $\mathrm{NaCl}$, they seemingly exhibited no reliable preference or aversion for them. In contrast, detection thresholds for sucrose and glucose correspond, at least in mice, significantly with preference thresholds reported in the literature (Bachmanov et al. 2001) most probably because the emotional value of these stimuli increases significantly as soon as they are detected (Eylam and Spector 2004). Moreover, one main limitation of the long-term TBC procedure is that post-ingestive measures can influence intake and, consequently, might confound the interpretation of taste effects. Indeed, it has been reported that increased avoidance of phenylthiocarbamide (PTC) with ascending concentrations, by SWR/J mice, was most possibly due to the development of a conditioned aversion for PTC over consecutive intake tests, rather than the expression of unconditioned avoidance due to its taste (St John et al. 2005). Taken together, the outcomes from the TBC should be cautiously interpreted considering the limitations of this procedure. Regardless, our findings indicated that the difference in ethanol consumption and preference observed between mock and siDAT mice cannot be accredited, at least, to differences in total fluid intake. 
It is probable that the palatability or taste sensitivity of ethanol varies between mock and siDAT groups. However, in our studies, there were no significant differences between the two groups of either preference for saccharin, or in avoidance of quinine solutions, suggesting that there were no differences in taste preference between groups. These results confirm and extend current data. Our finding that both C57BL/6 experimental groups had higher saccharin preference ratios is consistent with earlier results from our laboratory (Bahi 2017; Bahi et al. 2016). Consistent with our results, there is evidence that C57BL/6 mice have higher intakes of several sweet compounds, such as saccharin (Belknap et al. 1993). Interestingly, a positive correlation has been found between ethanol intake and sweet solution intake among other inbred strains of mice (Belknap et al. 1993) and rats (Stewart et al. 1994). However, our findings are at odds with the work of Costa and colleagues who tested both WT and DAT KO mice and found that the latter had stronger preference toward hedonically sweet tastant (sucrose $400 \mathrm{mM}$ ) in TBC test (Costa et al. 2007). Because these studies include an extensive variability of nutritive (sucrose) and nonnutritive (saccharin) sweeteners (Lush 1989), some of which are supposed to have no postingestive effects, the findings indicate that there is a genetically determined link between alcohol intake and sweet taste perception and we conclude that considerable caution must be exercised in interpreting the results using DAT KO mice.

Because, in humans, there is a significant link between predisposition to alcoholism and lower sensitivity to bitterness (Pelchat and Danowski 1992), and the fact that the taste of ethanol has a bitter component to rats (Kiefer et al. 1990), a preference for the bitter tastant (quinine) might predict increased ethanol consumption. Still, we found no indication for such connection. In fact, despite of the significant differences in ethanol intake between mock- and siDAT-injected mice, both groups showed significant and similar tendencies to avoid the two quinine solutions. However, our results are not in line with the observations that DAT KO mice exhibited no significant difference in licking between quinine and water (Costa et al. 2007), suggesting once again that these mice display reduced aversion to quinine. Thus, the altered taste sensitivity in DAT KO mice remains to be explained.

Several studies have used systemic injection of pharmacological agents or constitutive knockout mice gene to study the effects of genes on ethanol consumption and preference, and most of these studies also evaluated the probability that saccharin, or sucrose, or quinine preference had been affected (Crabbe et al. 2006). As in the current study, many of those studies used the same mice tested for ethanol consumption and preference to measure intake and preference for tastants. We propose that controlling ethanol preference studies for taste sensitivity, and preference or avoidance of other tastants, must be carefully interpreted if tastants are presented after ethanol. The safest way would be a between-subjects design for each tastant, starting with naive mice. Also, a serial procedure, using naive mice, in which saccharin preference is left to last could be a more adequate alternative as reported previously (Crabbe et al. 2011).

Our data reveal a significant decrease in alcohol intake and preference upon siDAT injection in the Nacc compared with mock controls. In this study, we used RTPCR, rather than immunohistochemistry, to verify DAT accumbal knocked down. A caveat to this approach remains the possibility of a "miss" in one or more mice. Indeed, Pearson linear regression analysis indicated that some mice retained levels of DAT that were very similar to control mice. Therefore, we cannot exclude the possibility that DAT may have been primarily knocked down in the dorsomedial striatum rather than the ventral striatum and findings should be interpreted with caution. Regardless, our hypothesis is that DAT knockdown resulted in enhanced dopamine levels in the Nacc. In fact, increased extracellular dopamine concentrations in the Nacc in response to alcohol are a direct biochemical evidence of the incentive properties of alcohol (Di Chiara and Imperato 1988). Furthermore, using immunoprecipitation followed by mass spectrometry, ras-specific guanine-nucleotide releasing factor 2 (Rasgrf2) has been isolated as a binding partner of DAT (Maiya et al. 2007). One can speculate that reduced DAT expression, following shRNA injection, would be accompanied by a significant reduction of Rasgrf2 expression levels in the Nacc, because after subchronic alcohol treatment, DAT mRNA expression in Rasgrf2 $\mathrm{KO}$ mice decreased compared to WT levels (Easton et al. 2014). Interestingly, the work by Stacey and colleagues showed an absence of a accumbal dopamine response in Rasgrf2 $\mathrm{KO}$ and a clear reduction in alcohol-induced reinforcement in these mice (Stacey et al. 2012). Taken together, these data suggest that abnormal dopamine activity in the Nacc following DAT knockdown might, at least in part, account for the decreased motivational and rewarding effects of ethanol observed in these mice.

Mechanistically, about the reduction in ethanol intake and preference we observed following siRNA injection, we can hypothesize that DAT knockdown may be associated with higher accumbal extracellular dopamine levels because of altered DAT mRNA expression and, consequently, reduced uptake, like in DAT KO mice (Giros et al. 1996). Because increased dopamine levels were associated with disrupted and desensitized D2 autoreceptors (Giros et al. 1996), because operant ethanol selfadministration in $\mathrm{D} 2$ receptor $\mathrm{KO}$ mice was reduced (Risinger et al. 2000), and D2 receptor antagonism 
decreased the acquisition of ethanol-induced conditioned taste aversion (Risinger et al. 1999), it is safe to speculate that altered D2 receptor expression and/or functions in the Nacc affected ethanol-related behaviors following DAT knockdown. In fact, many studies have suggested that low D2 receptors' availability is related with alcohol abuse. In fact, Volkow and colleagues showed that D2 receptors' availability was significantly higher in caudate and ventral striatum in nonalcoholic subjects with a family history of alcoholism than in nonalcoholic subjects with a negative family history, suggesting that higher D2 receptors' levels may be protective against alcoholism (Volkow et al. 2006). Also, preclinical studies demonstrated that injection of D2-expressing adenoviral vector, into the Nacc of rats previously trained to self-administer alcohol, was associated with marked reductions in alcohol consumption and preference (43 and 64\%, respectively) (Thanos et al. 2001). The same group also reported that D2 overexpression significantly decreased alcohol consumption $(48 \%)$ and preference $(37 \%)$ in alcoholpreferring rats (Thanos et al. 2004), suggesting that high D2 receptor expression might protect against excessive alcohol intake and preference in subjects with prior history of alcoholism or in those who are genetically predisposed to self-administer alcohol.

These findings suggest a role for DAT as a possible therapeutic drug target that may tackle alcoholism and alcohol use disorders in humans. In fact, several DAT inhibitors are now available for treatment of other disorders such as obesity, narcolepsy, and ADHD. Therefore, there is already significant clinical experience in the use of these medications that could guide strategies for their use to treat alcoholism. Nevertheless, it will be crucial and indispensable to evaluate the risks associated with treatment against risks associated with continued use of the abused stimulant. Finally, data from both preclinical and clinical studies indicate that patients can be safely maintained on DAT inhibitors or substrates despite constant access to cocaine or other abuse stimulants [for review, see Howell and Negus 2014].

In conclusion, the present study establishes an important role for DAT in ethanol-related behaviors; also, we have demonstrated that, regardless of sex, the localized gene knockdown in the Nacc reduced voluntary ethanol intake and preference in a way that cannot be accredited to altered total fluid intake levels, taste preference/neophobia, or ethanol metabolism/absorption. Further research involving behavioral, biochemical, and electrophysiological assay will clarify the mechanism(s) by which DAT exerts its effects on ethanol consumption.

Acknowledgments The authors would like to acknowledge Mrs. Christine Deforel-Poncet and Dr. Frederic Boyer for their technical assistance with the lentiviral vectors' preparation. The authors are also grateful to Mr. Mohamed Shafiullah and Dr. Mahmoud Hag Ali from the Central Animal Facility for their advice on animal care and welfare.

Authors' contribution $\mathrm{AB}$ designed the study and wrote the protocol. $\mathrm{AB}$ and JLD managed the literature searches and analyses. AB undertook the statistical analysis, and AB and JLD wrote the first draft of the manuscript. All authors contributed to and have approved the final manuscript.

Role of the funding source $\mathrm{AB}$ was supported by grants from the UAE University (No. NP/13/05) and the National Research foundation (No. 31M082). JLD received grants from the Swiss National Science Foundation 3100-059350 and 3100AO-100686. The funders had no further role in study design, analysis, writing of the report, or in the decision to submit the paper for publication.

\section{Compliance with ethical standards}

Conflict of interest The authors declare that they have no conflict of interest.

Publisher's Note Springer Nature remains neutral with regard to jurisdictional claims in published maps and institutional affiliations.

\section{References}

Adriani W, Boyer F, Gioiosa L, Macri S, Dreyer JL, Laviola G (2009) Increased impulsive behavior and risk proneness following lentivirus-mediated dopamine transporter over-expression in rats' nucleus accumbens. Neuroscience 159:47-58

Adriani W, Boyer F, Leo D, Canese R, Podo F, Perrone-Capano C, Dreyer JL, Laviola G (2010) Social withdrawal and gambling-like profile after lentiviral manipulation of DAT expression in the rat accumbens. Int J Neuropsychopharmacol 13:1329-1342

Al Ameri M, Al Mansouri S, Al Maamari A, Bahi A (2014) The histone deacetylase (HDAC) inhibitor valproic acid reduces ethanol consumption and ethanol-conditioned place preference in rats. Brain Res 1583:122-131

Bachmanov AA, Tordoff MG, Beauchamp GK (1996) Ethanol consumption and taste preferences in C57BL/6ByJ and 129/J mice. Alcohol Clin Exp Res 20:201-206

Bachmanov AA, Tordoff MG, Beauchamp GK (2001) Sweetener preference of C57BL/6ByJ and 129P3/J mice. Chem Senses 26:905-913

Bahi A (2016) The oxytocin receptor impairs ethanol reward in mice. Physiol Behav 139:321-327

Bahi A (2017) Decreased anxiety, voluntary ethanol intake and ethanolinduced CPP acquisition following activation of the metabotropic glutamate receptor 8 "mGluR8". Pharmacol Biochem Behav 155: $32-42$

Bahi A, Al Mansouri S, Al Maamari E (2016) Nucleus accumbens lentiviral-mediated gain of function of the oxytocin receptor regulates anxiety- and ethanol-related behaviors in adult mice. Physiol Behav 164:249-258

Bahi A, Boyer F, Bussard G, Dreyer JL (2005a) Silencing dopamine D3receptors in the nucleus accumbens shell in vivo induces changes in cocaine-induced hyperlocomotion. Eur J Neurosci 21:3415-3426

Bahi A, Boyer F, Gumy C, Kafri T, Dreyer JL (2004) In vivo gene delivery of urokinase-type plasminogen activator with regulatable lentivirus induces behavioural changes in chronic cocaine administration. Eur J Neurosci 20:3473-3488 
Bahi A, Boyer F, Kolira M, Dreyer JL (2005b) In vivo gene silencing of CD81 by lentiviral expression of small interference RNAs suppresses cocaine-induced behaviour. J Neurochem 92:1243-1255

Bahi A, Dreyer JL (2012) Involvement of nucleus accumbens dopamine D1 receptors in ethanol drinking, ethanol-induced conditioned place preference, and ethanol-induced psychomotor sensitization in mice. Psychopharmacology 222:141-153

Bahi A, Dreyer JL (2014) Lentiviral vector-mediated dopamine d3 receptor modulation in the rat brain impairs alcohol intake and ethanol-induced conditioned place preference. Alcohol Clin Exp Res 38:2369-2376

Bahi A, Nurulain SM, Ojha S (2014) Ethanol intake and ethanolconditioned place preference are reduced in mice treated with the bioflavonoid agent naringin. Alcohol 48:677-685

Bahi A, Sadek B, Schwed SJ, Walter M, Stark H (2013) Influence of the novel histamine $\mathrm{H}(3)$ receptor antagonist ST1283 on voluntary alcohol consumption and ethanol-induced place preference in mice. Psychopharmacology 228:85-95

Belknap JK, Crabbe JC, Young ER (1993) Voluntary consumption of ethanol in 15 inbred mouse strains. Psychopharmacology 112:503-510

Benade V, Nirogi R, Bhyrapuneni G, Daripelli S, Ayyanki G, Irappanavar S, Ponnamaneni R, Manoharan A (2017) Mechanistic evaluation of tapentadol in reducing the pain perception using in-vivo brain and spinal cord microdialysis in rats. Eur J Pharmacol 809:224-230

Benoit-Marand M, Jaber M, Gonon F (2000) Release and elimination of dopamine in vivo in mice lacking the dopamine transporter: functional consequences. Eur J Neurosci 12:2985-2992

Bergstrom KA, Tupala E, Tiihonen J (2001) Dopamine transporter in vitro binding and in vivo imaging in the brain. Pharmacol Toxicol 88:287-293

Boyer F, Dreyer JL (2008) The role of gamma-synuclein in cocaineinduced behaviour in rats. Eur J Neurosci 27:2938-2951

Brunelin J, Fecteau S, Suaud-Chagny MF (2013) Abnormal striatal dopamine transmission in schizophrenia. Curr Med Chem 20:397-404

Cartier E, Hamilton PJ, Belovich AN, Shekar A, Campbell NG, Saunders C, Andreassen TF, Gether U, Veenstra-Vanderweele J, Sutcliffe JS, Ulery-Reynolds PG, Erreger K, Matthies HJ, Galli A (2015) Rare autism-associated variants implicate syntaxin 1 (STX1 R26Q) phosphorylation and the dopamine transporter (hDAT R51W) in dopamine neurotransmission and behaviors. EBioMedicine 2:135-146

Cass WA, Zahniser NR, Flach KA, Gerhardt GA (1993) Clearance of exogenous dopamine in rat dorsal striatum and nucleus accumbens: role of metabolism and effects of locally applied uptake inhibitors. J Neurochem 61:2269-2278

Chen YC, Lai WS (2010) Behavioural phenotyping of dopamine transporter knockdown mice using local small interference RNA. Behav Brain Res 214:475-479

Ciliax BJ, Drash GW, Staley JK, Haber S, Mobley CJ, Miller GW, Mufson EJ, Mash DC, Levey AI (1999) Immunocytochemical localization of the dopamine transporter in human brain. J Comp Neurol 409:38-56

Costa RM, Gutierrez R, de Araujo IE, Coelho MR, Kloth AD, Gainetdinov RR, Caron MG, Nicolelis MA, Simon SA (2007) Dopamine levels modulate the updating of tastant values. Genes Brain Behav 6:314-320

Crabbe JC, Harkness JH, Spence SE, Huang LC, Metten P (2012) Intermittent availability of ethanol does not always lead to elevated drinking in mice. Alcohol Alcohol 47:509-517

Crabbe JC, Phillips TJ, Harris RA, Arends MA, Koob GF (2006) Alcohol-related genes: contributions from studies with genetically engineered mice. Addict Biol 11:195-269

Crabbe JC, Spence SE, Brown LL, Metten P (2011) Alcohol preference drinking in a mouse line selectively bred for high drinking in the dark. Alcohol 45:427-440

Crabbe JC, Wahlsten D, Dudek BC (1999) Genetics of mouse behavior: interactions with laboratory environment. Science 284:1670-1672
Danilovich N, Mastrandrea LD, Cataldi L, Quattrin T (2014) Methylphenidate decreases fat and carbohydrate intake in obese teenagers. Obesity (Silver Spring) 22:781-785

Di Chiara G, Imperato A (1988) Drugs abused by humans preferentially increase synaptic dopamine concentrations in the mesolimbic system of freely moving rats. Proc Natl Acad Sci U S A 85:5274-5278

Dole VP (1986) On the relevance of animal models to alcoholism in humans. Alcohol Clin Exp Res 10:361-363

Easton AC, Rotter A, Lourdusamy A, Desrivieres S, Fernandez-Medarde A, Biermann T, Fernandes C, Santos E, Kornhuber J, Schumann G, Muller CP (2014) Rasgrf2 controls dopaminergic adaptations to alcohol in mice. Brain Res Bull 109:143-150

Eylam S, Spector AC (2002) The effect of amiloride on operantly conditioned performance in an $\mathrm{NaCl}$ taste detection task and $\mathrm{NaCl}$ preference in C57BL/6J mice. Behav Neurosci 116:149-159

Eylam S, Spector AC (2004) Stimulus processing of glycine is dissociable from that of sucrose and glucose based on behaviorally measured taste signal detection in Sac 'taster' and 'non-taster' mice. Chem Senses 29:639-649

Femenia T, Manzanares J (2012) Increased ethanol intake in prodynorphin knockout mice is associated to changes in opioid receptor function and dopamine transmission. Addict Biol 17:322-337

Franklin KBJ, Paxinos G (1997) The mouse brain in stereotaxic coordinates. Academic Press, SanDiego

Gainetdinov RR, Caron MG (2003) Monoamine transporters: from genes to behavior. Annu Rev Pharmacol Toxicol 43:261-284

Gainetdinov RR, Mohn AR, Caron MG (2001) Genetic animal models: focus on schizophrenia. Trends Neurosci 24:527-533

Gether U, Andersen PH, Larsson OM, Schousboe A (2006) Neurotransmitter transporters: molecular function of important drug targets. Trends Pharmacol Sci 27:375-383

Giros B, Jaber M, Jones SR, Wightman RM, Caron MG (1996) Hyperlocomotion and indifference to cocaine and amphetamine in mice lacking the dopamine transporter. Nature 379:606-612

Hall FS, Sora I, Uhl GR (2003) Sex-dependent modulation of ethanol consumption in vesicular monoamine transporter 2 (VMAT2) and dopamine transporter (DAT) knockout mice. Neuropsychopharmacology 28:620-628

Hesse S, Muller U, Lincke T, Barthel H, Villmann T, Angermeyer MC, Sabri O, Stengler-Wenzke K (2005) Serotonin and dopamine transporter imaging in patients with obsessive-compulsive disorder. Psychiatry Res 140:63-72

Hirth N, Meinhardt MW, Noori HR, Salgado H, Torres-Ramirez O, Uhrig S, Broccoli L, Vengeliene V, Rossmanith M, Perreau-Lenz S, Kohr G, Sommer WH, Spanagel R, Hansson AC (2016) Convergent evidence from alcohol-dependent humans and rats for a hyperdopaminergic state in protracted abstinence. Proc Natl Acad Sci U S A 113:3024-3029

Howell LL, Negus SS (2014) Monoamine transporter inhibitors and substrates as treatments for stimulant abuse. Adv Pharmacol 69:129176

Kasahara Y, Arime Y, Kubo Y, Fukui A, Sora I (2011) Neuronal development of the hyperdopaminergic animal model. Nihon Shinkei Seishin Yakurigaku Zasshi 31:195-199

Kiefer SW, Bice PJ, Orr MR, Dopp JM (1990) Similarity of taste reactivity responses to alcohol and sucrose mixtures in rats. Alcohol 7: $115-120$

Kume K, Kume S, Park SK, Hirsh J, Jackson FR (2005) Dopamine is a regulator of arousal in the fruit fly. J Neurosci 25:7377-7384

Laine TP, Ahonen A, Torniainen P, Heikkila J, Pyhtinen J, Rasanen P, Niemela O, Hillbom M (1999) Dopamine transporters increase in human brain after alcohol withdrawal. Mol Psychiatry 4:189-191 104-5

Li B, Arime Y, Hall FS, Uhl GR, Sora I (2010) Impaired spatial working memory and decreased frontal cortex BDNF protein level in dopamine transporter knockout mice. Eur J Pharmacol 628:104-107 
Li TK, Lumeng L, McBride WJ, Waller MB (1979) Progress toward a voluntary oral consumption model of alcoholism. Drug Alcohol Depend 4:45-60

Lim JP, Zou ME, Janak PH, Messing RO (2012) Responses to ethanol in C57BL/6 versus C57BL/6 x 129 hybrid mice. Brain Behav 2:22-31

Liu H, Dong F, Meng Z, Zhang B, Tan J, Wang Y (2010) Evaluation of Tourette's syndrome by (99m)Tc-TRODAT-1 SPECT/CT imaging. Ann Nucl Med 24:515-521

Lush IE (1989) The genetics of tasting in mice. VI. Saccharin, acesulfame, dulcin and sucrose. Genet Res 53:95-99

Ma SY, Ciliax BJ, Stebbins G, Jaffar S, Joyce JN, Cochran EJ, Kordower JH, Mash DC, Levey AI, Mufson EJ (1999) Dopamine transporterimmunoreactive neurons decrease with age in the human substantia nigra. J Comp Neurol 409:25-37

Madras BK, Miller GM, Fischman AJ (2005) The dopamine transporter and attention-deficit/hyperactivity disorder. Biol Psychiatry 57:1397-1409

Maiya R, Ponomarev I, Linse KD, Harris RA, Mayfield RD (2007) Defining the dopamine transporter proteome by convergent biochemical and in silico analyses. Genes Brain Behav 6:97-106

Middaugh LD, Kelley BM, Bandy AL, McGroarty KK (1999) Ethanol consumption by $\mathrm{C} 57 \mathrm{BL} / 6$ mice: influence of gender and procedural variables. Alcohol 17:175-183

Morice E, Denis C, Giros B, Nosten-Bertrand M (2010) Evidence of long-term expression of behavioral sensitization to both cocaine and ethanol in dopamine transporter knockout mice. Psychopharmacology 208:57-66

Moron JA, Brockington A, Wise RA, Rocha BA, Hope BT (2002) Dopamine uptake through the norepinephrine transporter in brain regions with low levels of the dopamine transporter: evidence from knock-out mouse lines. J Neurosci 22:389-395

Muller-Vahl KR, Loeber G, Kotsiari A, Muller-Engling L, Frieling H (2017) Gilles de la Tourette syndrome is associated with hypermethylation of the dopamine D2 receptor gene. J Psychiatr Res 86:1-8

Naassila M, Ledent C, Daoust M (2002) Low ethanol sensitivity and increased ethanol consumption in mice lacking adenosine A2A receptors. J Neurosci 22:10487-10493

Pelchat ML, Danowski S (1992) A possible genetic association between PROP-tasting and alcoholism. Physiol Behav 51:1261-1266

Perona MT, Waters S, Hall FS, Sora I, Lesch KP, Murphy DL, Caron M, Uhl GR (2008) Animal models of depression in dopamine, serotonin, and norepinephrine transporter knockout mice: prominent effects of dopamine transporter deletions. Behav Pharmacol 19:566-574

Pogarell O, Poepperl G, Mulert C, Hamann C, Sadowsky N, Riedel M, Moeller HJ, Hegerl U, Tatsch K (2005) SERT and DAT availabilities under citalopram treatment in obsessive-compulsive disorder (OCD). Eur Neuropsychopharmacol 15:521-524

Pogorelov VM, Rodriguiz RM, Insco ML, Caron MG, Wetsel WC (2005) Novelty seeking and stereotypic activation of behavior in mice with disruption of the Dat1 gene. Neuropsychopharmacology 30:18181831

Ralph RJ, Paulus MP, Fumagalli F, Caron MG, Geyer MA (2001) Prepulse inhibition deficits and perseverative motor patterns in dopamine transporter knock-out mice: differential effects of D1 and D2 receptor antagonists. J Neurosci 21:305-313

Richtand NM, Kelsoe JR, Segal DS, Kuczenski R (1995) Regional quantification of dopamine transporter mRNA in rat brain using a ribonuclease protection assay. Neurosci Lett 200:73-76

Richter CP (1926) A study of the effect of moderate doses of alcohol on the growth and behavior of the rat. J Exp Zool 44:397-418

Risinger FO, Brown MM, Oakes RA, Love JA (1999) Effects of haloperidol or SCH-23390 on ethanol-induced conditioned taste aversion. Alcohol 18:139-145

Risinger FO, Freeman PA, Rubinstein M, Low MJ, Grandy DK (2000) Lack of operant ethanol self-administration in dopamine D2 receptor knockout mice. Psychopharmacology 152:343-350
Rosenwasser AM, Fixaris MC, Crabbe JC, Brooks PC, Ascheid S (2013) Escalation of intake under intermittent ethanol access in diverse mouse genotypes. Addict Biol 18:496-507

Salvatore MF, Hudspeth O, Arnold LE, Wilson PE, Stanford JA, MacTutus CF, Booze RM, Gerhardt GA (2004) Prenatal cocaine exposure alters potassium-evoked dopamine release dynamics in rat striatum. Neuroscience 123:481-490

Sander T, Harms H, Podschus J, Finckh U, Nickel B, Rolfs A, Rommelspacher H, Schmidt LG (1997) Allelic association of a dopamine transporter gene polymorphism in alcohol dependence with withdrawal seizures or delirium. Biol Psychiatry 41: 299-304

Savelieva KV, Caudle WM, Findlay GS, Caron MG, Miller GW (2002) Decreased ethanol preference and consumption in dopamine transporter female knock-out mice. Alcohol Clin Exp Res 26:758-764

Schmitt KC, Reith ME (2010) Regulation of the dopamine transporter: aspects relevant to psychostimulant drugs of abuse. Ann N Y Acad Sci 1187:316-340

St John SJ, Pour L, Boughter JD Jr (2005) Phenylthiocarbamide produces conditioned taste aversions in mice. Chem Senses 30:377-382

Stacey D, Bilbao A, Maroteaux M, Jia T, Easton AC, Longueville S, Nymberg C, Banaschewski T, Barker GJ, Buchel C, Carvalho F, Conrod PJ, Desrivieres S, Fauth-Buhler M, Fernandez-Medarde A, Flor H, Gallinat J, Garavan H, Bokde AL, Heinz A, Ittermann B, Lathrop M, Lawrence C, Loth E, Lourdusamy A, Mann KF, Martinot JL, Nees F, Palkovits M, Paus T, Pausova Z, Rietschel M, Ruggeri B, Santos E, Smolka MN, Staehlin O, Jarvelin MR, Elliott P, Sommer WH, Mameli M, Muller CP, Spanagel R, Girault JA, Schumann G (2012) RASGRF2 regulates alcohol-induced reinforcement by influencing mesolimbic dopamine neuron activity and dopamine release. Proc Natl Acad Sci U S A 109: $21128-21133$

Stewart RB, Russell RN, Lumeng L, Li TK, Murphy JM (1994) Consumption of sweet, salty, sour, and bitter solutions by selectively bred alcohol-preferring and alcohol-nonpreferring lines of rats. Alcohol Clin Exp Res 18:375-381

Szot P, White SS, Veith RC (1997) Effect of pentylenetetrazol on the expression of tyrosine hydroxylase mRNA and norepinephrine and dopamine transporter mRNA. Brain Res Mol Brain Res 44:46-54

Thanos PK, Taintor NB, Rivera SN, Umegaki H, Ikari H, Roth G, Ingram DK, Hitzemann R, Fowler JS, Gatley SJ, Wang GJ, Volkow ND (2004) DRD2 gene transfer into the nucleus accumbens core of the alcohol preferring and nonpreferring rats attenuates alcohol drinking. Alcohol Clin Exp Res 28:720-728

Thanos PK, Volkow ND, Freimuth P, Umegaki H, Ikari H, Roth G, Ingram DK, Hitzemann R (2001) Overexpression of dopamine D2 receptors reduces alcohol self-administration. J Neurochem 78: 1094-1103

Tiihonen J, Vilkman H, Rasanen P, Ryynanen OP, Hakko H, Bergman J, Hamalainen T, Laakso A, Haaparanta-Solin M, Solin O, Kuoppamaki M, Syvalahti E, Hietala J (1998) Striatal presynaptic dopamine function in type 1 alcoholics measured with positron emission tomography. Mol Psychiatry 3:156-161

Tomita J, Ueno T, Mitsuyoshi M, Kume S, Kume K (2015) The NMDA receptor promotes sleep in the fruit fly, Drosophila melanogaster. PLoS One 10:e0128101

Ueno T, Tomita J, Kume S, Kume K (2012) Dopamine modulates metabolic rate and temperature sensitivity in Drosophila melanogaster. PLoS One 7:e31513

Volkow ND, Wang GJ, Begleiter H, Porjesz B, Fowler JS, Telang F, Wong C, Ma Y, Logan J, Goldstein R, Alexoff D, Thanos PK (2006) High levels of dopamine D2 receptors in unaffected 
members of alcoholic families: possible protective factors. Arch Gen Psychiatry 63:999-1008

Volkow ND, Wang GJ, Fowler JS, Logan J, Hitzemann R, Ding YS,

Pappas N, Shea C, Piscani K (1996) Decreases in dopamine receptors but not in dopamine transporters in alcoholics. Alcohol Clin Exp Res 20:1594-1598

Weiss S, Nosten-Bertrand M, McIntosh JM, Giros B, Martres MP (2007) Nicotine improves cognitive deficits of dopamine transporter knock- out mice without long-term tolerance. Neuropsychopharmacology 32:2465-2478

Yoneyama N, Crabbe JC, Ford MM, Murillo A, Finn DA (2008) Voluntary ethanol consumption in 22 inbred mouse strains. Alcohol 42:149-160 